Repository of the Max Delbrück Center for Molecular Medicine (MDC) Berlin (Germany)

http://edoc. molc-berlin.de/13936/

Germline transgenesis in pigs by cytoplasmic microinjection of sleeping beauty transposons

Ivics, Z., Garrels, W., Mates, L., Yau, T.Y., Bashir, S., Zidek, V., Landa, V., Geurts, A., Pravenec, M., Ruelicke, T., Kues, W.A., Izsvak, Z. 


\title{
Germline transgenesis in pigs by cytoplasmic microinjection of
}

\section{Sleeping Beauty transposons}

\author{
Zoltán Ivics ${ }^{1, \S, *}$, Wiebke Garrels ${ }^{2, \S}$, Lajos Mátés ${ }^{3}$, Tien Yin Yau ${ }^{4}$, Sanum Bashir ${ }^{5}$, Vaclav Zidek ${ }^{6}$, Vladimír \\ Landa $^{6}$, Aron Geurts ${ }^{7}$, Michal Pravenec ${ }^{6}$, Thomas Rülicke ${ }^{4}$, Wilfried A. Kues ${ }^{2,{ }^{*}}$ and Zsuzsanna Izsvák ${ }^{5,{ }^{*}}$
}

Division of Medical Biotechnology, Paul Ehrlich Institute, Langen, Germany

Friedrich-Loeffler-Institut, Institut für Nutztiergenetik, Neustadt, Germany

Biological Research Centre, Hungarian Academy of Sciences, Szeged, Hungary

Institute of Laboratory Animal Science, University of Veterinary Medicine Vienna, Vienna, Austria

Max Delbrück Center for Molecular Medicine, Berlin, Germany

Institute of Physiology, Academy of Sciences of the Czech Republic, Prague, Czech Republic

Department of Physiology, Medical College of Wisconsin, WI, USA

equal contribution

* For correspondence:

Zoltan Ivics

Wilfried A. Kues

Paul Ehrlich Institute

Paul Ehrlich Str. 51-59

Friedrich-Loeffler-Institute

D-63225 Langen

Höltystrasse 10

Germany

Email: zoltan.ivics@pei.de

D-31535 Neustadt

Germany

Email: wilfried.kues@fli.bund.de

Zsuzsanna Izsvak

Max Delbrück Center for Molecular Medicine

Robert Rössle Strasse 10

13125 Berlin

Germany

Email: zizsvak@mdc-berlin.de

\section{Key words:}

Targeted genome engineering, functional genomics, large animal models, gene insertion, cytoplasmic plasmid microinjection, active transgenesis, in ovo transposition

\section{Key references:}

Katter K, Geurts AM, Hoffmann O, Mátés L, Landa V, Hiripi L, Moreno C, Lazar J, Bashir S, Zidek V, Popova E, Jerchow B, Becker K, Devaraj A, Walter I, Grzybowksi M, Corbett M, Filho AR, Hodges MR, Bader M, Ivics Z, Jacob HJ, Pravenec M, Bosze Z, Rülicke T, Izsvák Z. Transposon-mediated transgenesis, transgenic rescue, and tissue-specific gene expression in rodents and rabbits. FASEB J. 2013, 27(3):930-41.

Garrels W, Mátés L, Holler S, Dalda A, Taylor U, Petersen B, Niemann H, Izsvák Z, Ivics Z, Kues WA.Germline transgenic pigs by Sleeping Beauty transposition in porcine zygotes and targeted integration in the pig genome. PLoS One. 2011, 6(8):e23573.

Mátés L, Chuah MK, Belay E, Jerchow B, Manoj N, Acosta-Sanchez A, Grzela DP, Schmitt A, Becker K, Matrai J, Ma L, Samara-Kuko E, Gysemans C, Pryputniewicz D, Miskey C, Fletcher B, VandenDriessche T, Ivics Z, Izsvák Z. Molecular evolution of a novel hyperactive Sleeping Beauty transposase enables robust stable gene transfer in vertebrates. Nat Genet. 2009, 41(6):753-61. 
The pig has emerged as an important large animal model in biomedical and pharmaceutical research. We describe a protocol for high-efficiency germline transgenesis and sustained transgene expression in pigs by using the Sleeping Beauty transposon system. The protocol is based on co-injection of a plasmid encoding the SB100X hyperactive transposase together with a second plasmid carrying a transgene flanked by binding sites for the transposase, into the cytoplasm of porcine zygotes. The transposase mediates excision of the transgene cassette from the plasmid vector and its permanent insertion into the genome to produce stable transgenic animals. This method compares favorably in terms of both efficiency and reliable transgene expression to classic pronuclear microinjection or somatic cell nuclear transfer, and offers comparable efficacies to lentiviral approaches, without limitations on vector design, issues of transgene silencing as well as the toxicity and biosafety concerns of working with viral vectors. Microinjection of the vectors into zygotes and transfer of the embryos to recipient animals can be performed in one day; generation of germline-transgenic lines by using this protocol takes approximately one year. 


\section{INTRODUCTION}

The pig has emerged as an important large mammalian model in biomedical and pharmaceutical research ${ }^{1-3}$. Pigs have been widely applied for studying infectious diseases, cardiovascular disease, atherosclerosis, wound healing, diabetes, ophthalmology, cancer and cell therapies, as well as for assessing the suitability of porcine xenotransplants for humans $\mathrm{s}^{2,4}$. In recent years, improved methods for transgenesis have made this model even more valuable ${ }^{5}$. Humanized pig models include those for retinitis pigmentosa ${ }^{6}$, cystic fibrosis ${ }^{7}$, Alzheimer's disease $^{8}$, Huntington's disease ${ }^{9}$, familial adenomatous polyposis ${ }^{10}$, and immunodeficiency ${ }^{11}$. However, transgenesis in the pig, most commonly achieved by pronuclear DNA injection (PNI) or by somatic cell nuclear transfer (SCNT), is an inefficient and expensive process, hampered by poor predictability of levels and patterns of transgene expression ${ }^{2,3,12-14}$. Gene targeting by homologous recombination is extremely inefficient in porcine somatic cells ${ }^{3}$, and porcine embryonic stem cells (ES) have not yet been established ${ }^{15}$. Recently, several groups described the derivation of porcine induced pluripotent cells (iPS) ${ }^{16-20}$, however, only low chimerism has been found after blastocyst complementation experiments ${ }^{21,22}$. The employment of porcine iPS cells in the SCNT method resulted in extremely low rates of born piglets ${ }^{23}$.

\section{Germline transgenesis in pigs}

$\mathrm{PNI}$ into porcine zygotes is inefficient (overall success rate of $\sim 1 \%$ per treated embryos) and cumbersome. In contrast to rodent species, porcine zygotes are opaque and the pronuclei are not readily visible. To visualize porcine pronuclei, a high speed centrifugation $(12000-15000 \times \mathrm{g})$ is required, which may have a negative impact on embryonic development. Successful injection of foreign DNA into a porcine pronucleus requires experienced technical skills, and results in a high ratio of lysed zygotes due to the particular vulnerability of the pronuclei. SCNT is currently the most commonly applied method for porcine transgenesis. The procedure includes gene transfer into primary somatic cells, screening of cells carrying the desired genetic modification, introduction of a genetically modified cell into an enucleated porcine oocyte and activation of the reconstructed embryo to initiate cleavage divisions $s^{3,7,8}$. The transfer of $>100$ reconstructed embryos to one surrogate animal is required 
to establish a pregnancy in the pig $^{7,8}$ and success rates of only 1-3 \% per reconstructed embryos have been achieved ${ }^{7,8}$. Furthermore, SCNT protocols are associated with a high workload, and partial genome reprogramming during SCNT commonly results in high rates of abortion and neonatal deaths.

In addition to PNI and SCNT, lentiviral transduction of zygotes ${ }^{24,25}$ and intracytoplasmatic sperm injection (ICSI) ${ }^{26,27}$ have been employed for transgenesis in the pig. Lentiviral transduction can produce high ratios of transgenic offspring (20-30\% transgenic offspring per treated embryos), but this technique frequently results in cell mosaicism and thus reduced germline transmission; the maximal cargo of foreign DNA with lentiviral vectors is about $7 \mathrm{kbp}$; and epigenetic silencing of the virally integrated constructs has been observed ${ }^{13}$. Another limitation is that a laboratory with biosafety level 2 is required for lentivirus production and handling. ICSI of membrane-damaged (dead) spermatozoa incubated with foreign DNA has been used to produce transgenic piglets; however, this method is technically demanding and the reported success rates are low $(<1 \%$ transgenic offspring per treated oocytes $)^{26}$.

\section{Transgenesis using the Sleeping Beauty transposon}

Transposons are non-viral, mobile DNA elements with a relatively simple composition. They contain a gene encoding for a transposase, flanked by inverted terminal repeats (ITRs) that carry binding sites for the transposase. For research purposes the transposase and the transposon are provided separately to allow controlled transposition. In such a bi-component vector systems a DNA sequence of interest (here, a transgene) can be cloned in place of the original transposase gene between the transposon ITRs, and mobilized by supplementing the transposase enzyme in trans as an expression plasmid or as in vitro synthesized mRNA (Fig. 1a). During transposition, the transposase excises the transposon from its donor plasmid and integrates it into a chromosomal locus (Fig. 1b). Based on fossil record of transposons that were active $>10$ million years ago in fish genomes, an ancient transposon was "awakened" (molecularly reconstructed) and named Sleeping Beauty (SB) after the Grimm brothers' fairy tale ${ }^{28}$. SB was the first transposon shown to be capable of efficient transposition in vertebrate cells, thereby opening new avenues for genetic engineering in animal models (reviewed 
in ref. 29). In addition to SB, the piggyBac and Tol2 transposons have also been developed for use in transgenic procedures ${ }^{29}$.

The SB system combines the advantages of retroviral vectors - permanent gene insertion into recipient genomes, with those of naked DNA molecules - simple and safe production and application. Because transposition is a cut-and-paste mechanism that does not involve reverse transcription, transposon-based vectors can tolerate larger and more complex transgenes and the SB system is not strictly limited by the size of expression cassettes ${ }^{30}$. Indeed, inserts as large as bacterial artificial chromosomes (BAC) were recently shown to transpose with SB at reasonable efficiencies in mouse $\mathrm{ESCs}^{31}$. When performing transgenesis, a single copy transgene insertion, which is not disturbing endogenous gene functions is desirable. Chromosomal integration of SB transposons is nearly random at the genome level resulting in $\sim 60 \%$ of the SB transposon integrations being intergenic ${ }^{32-35}$. Furthermore, transposons have been shown to efficiently deliver a wide variety of transgene cassettes (reviewed in refs. 29, 36 and 37).

Because the transposase is only transiently present in the cell, the integrated transposable element is stable (i.e., will not undergo further rounds of transposition), thereby rendering transposons easily controllable, conditional DNA delivery tools that can be used for versatile applications, including germline gene transfer. We have recently developed a hyperactive variant of the SB transposase, called SB100X, by in vitro evolution ${ }^{38}$. SB100X supports efficient germline transgenesis in mice ${ }^{38-40}$, rats $^{39,40}$, rabbits ${ }^{39,41}$ and pigs ${ }^{42}$. We optimized the SB100X-mediated protocol by carefully titrating the relative amounts of transposase and transposon to obtain optimal rates of transgenesis to generate founders, and extensively evaluated it for efficacy, toxicity, mosaicism, germline transmission, insertion site preferences, transgene copy number and silencing. One of the most important aspects of using this protocol is that no major mosaicism was observed, and transgene expression was maintained for several generations in all species tested. This lack of mosaicism is in sharp contrast to current PNI or viral approaches to transgenesis. This is likely due to the very nature of transgene integration: transposition results in precise (i. e., the ends of the integrating DNA are well defined) 
genomic integration of monomeric transgene units within a short timeframe following administration. Furthermore, unlike retroviral vectors ${ }^{43-46}$, SB100X transposase-catalyzed transgene integration does not seem to trigger transcriptional silencing ${ }^{34,39}$. Importantly, SB transposon-tagged genomic loci are suitable for recombinase-mediated cassette exchange (RMCE) ${ }^{47}$, allowing targeted genome engineering $^{5,42}$.

Transposase-catalyzed DNA integration seems to favor transcriptionally permissive loci, and all transgenic pigs we have examined, from the founder to the F2 generation showed the expected expression patterns ${ }^{42,48}$. Thus, transposition-mediated transgenesis compares favorably to current alternatives, particularly if the overall success rates of 6-8 \% (ratio of transgenic animals with desired phenotype per treated zygotes) and the success rates of $40-60 \%$ of transgenic founders per born animals are taken into account. The application of the Sleeping Beauty transposon system described here will significantly enhance the porcine genomic toolbox, and is expected to be adaptable to other farm animal species, including cattle.

\section{Limitations}

DNA transposons, including SB, are regulated by overproduction inhibition, which means that overexpression of the transposase has a negative effect on transposition ${ }^{34,49}$. The practical consequence of this phenomenon is that an optimal ratio of transposon donor plasmid and transposase mRNA needs to be established. As a rule of thumb, the injection mixture should contain $10 \mathrm{ng} / \mu \mathrm{l}$ transposon and $5 \mathrm{ng} / \mu \mathrm{l}$ transposase plasmids for an SB vector of a total size of $\sim 6.1 \mathrm{~kb}$ containing $\mathrm{a} \sim 2.5 \mathrm{~kb}$ transgene cassette ${ }^{38}$. For larger transgenes, the concentration of the donor plasmid in the microinjection mixture has to be increased to maintain optimal molar ratios between transposon and transposase.

Although transposition in ovo does not allow pre-screening for potential transgenics, the high ratio of transgenic offspring compensates for this limitation. As an alternative to the direct embryo injection described here, both the $\mathrm{SB}^{50-52}$ and the piggyBac ${ }^{53}$ transposon systems have been used to 
genetically modify porcine cells in vitro, which were subsequently used as donors in SCNT for pig transgenesis.

\section{Experimental design}

We provide a comprehensive protocol for the generation of germline transgenic pigs. We describe the use of Sleeping Beauty transposon vectors, animal breeding protocols, cytoplasmic microinjection to introduce plasmids into fertilized oocytes, and PCR-based genotyping protocols for the identification of transgenic animals.

The generation of transgenic pigs is achieved through the co-injection of a vector carrying a gene of interest cloned between the ITRs of SB and an expression vector that produces the transposase (Fig. 1) into the cytoplasm of a zygote ${ }^{5,42}$. Cytoplasmic injection (CPI) (Fig. 2a, b) is a relatively gentle injection method that avoids high-speed centrifugation of porcine zygotes and invasive removal of metaphase plates from porcine oocytes, which is an essential step of SCNT. The developmental competence of mammalian zygotes is not or only minimally affected by $\mathrm{CPI}^{54,55}$, thus allowing for the reduction of animal numbers used. The protocol consists of the following major parts:

- Preparation of plasmids for microinjection (Steps 1-7). These steps include molecular cloning of a GOI into SB transposon vectors and purification of the plasmids; and preparation of a mixture consisting of the purified transposon plasmid and the plasmid that expresses the transposase. One useful way to detect transgene integration and expression is to employ a fluorescent reporter protein, such as Venus, which is an optimized (brighter) derivative of the enhanced yellow fluorescent protein (EYFP). We have previously demonstrated that an SB transposon carrying a CAGGS (CMV enhancer, chicken beta actin promoter)-driven Venus transgene (pT2-RMCE-Venus) facilitates the detection of transgenic animals ${ }^{38,39,48}$.

- $\quad$ Transgenesis with SB in pigs (Steps 8-77). These steps include superovulation of sows and collection of zygotes, microinjection of the plasmid mixture into zygotes, surgical embryo transfer to recipient sows followed by after-care of recipient animals and ultrasound scanning for implantations. To set up the CPI method, it may be helpful to start with in vitro culture of 
microinjected embryos to allow the assessment of ratios of successful injections and viable embryos $^{54}$. In vitro culture for 5 days should lead to development of blastocyst stages, consisting of an inner cell mass, the trophoblast and a central, fluid-filled cavity ${ }^{54}$. The Venus transposon allows a direct assessment of successfully injected embryos by fluorescence microscopy. In addition, mock injections of zygotes with buffer or a non-transposon plasmids can be performed as controls. However, due to scarcity of porcine zygotes, it is recommended to perform the injections only with the transposon plasmids mix. Finally, phenotyping and imaging of Venus-expressing transgenic pigs are described.

- Genotyping of transgenic animals (Steps 78-106). These steps include PCR-based analysis of F0 as well as F1 offspring to establish founders and germline transmission. A simple, quick PCR test can be applied to determine the presence of integrated transposon sequences from genomic DNA samples. The PCR primers amplify sequences in the left ITR of SB; thus, this protocol can be universally applied irrespective of the gene of interest that was cloned in the SB vector. In order to assess copy numbers of integrated transposons and map the genomic integration sites, a ligation-mediated PCR procedure is applied ${ }^{56}$. The procedure consists of a restriction enzyme digest of the genomic DNA, ligation of an oligonucleotide adapter to the ends of the fragmented DNA, PCR amplification of a transgene/genomic DNA junction in two rounds of nested PCR with primers specific to the adapter and to the ITRs of the SB transposon, and sequencing of the junctions to map the insertion to the reference genome ${ }^{57}$. Finally, a locus-specific PCR is applied to distinguish and track the individual integrations in the F1 and later generations.

Another issue to consider is the level of expertise needed to implement the protocol. The protocol requires access to a pig animal quarter, equipped with a surgical room. The animal caretaker must be trained in methods of reproductive biology, animal welfare and dealing with genetically modified organisms. For surgical embryo transfer a surgical team consisting of a surgeon, a technician for 
sterile assistance, a technician for non-sterile assistance, a technician for anesthesia, and a technician for pre- and post-operative care of the animals is required.

\section{MATERIALS}

\section{Reagents}

\section{Animals}

The animals are provided by the institutional pig quarter. Donors: 5 sows (German landrace, 6 months old, before first heat). Surrogate mothers: 3 sows (German landrace, 7-9 months old, after first heat). Boars: 1-2 trained boars (9-36 months old) for collection of semen; alternatively, boar semen can be ordered from a commercial supplier (for example: Besamungsstation Weser-Ems, Cloppenburg).

! Caution Animals have to be maintained and handled according to the national and institutional laws for animal welfare, and genetically modified organisms. Approval for the planned experiments may have to be obtained from an external ethics committee.

! Caution All animal requisitions, housing, treatment and procedures must conform to all national and institutional laws, guidelines and regulations.

\section{Molecular biology reagents and animal work}

- Agarose (DNase, RNase none detected) (Sigma-Aldrich, cat no. A4718)

- Ethidium bromide (10 mg/ml) (Sigma-Aldrich, cat no. E1510) ! Caution This is a hazardous chemical. Avoid contact with skin, eyes and airways.

- Bfal restriction endonuclease (New England Biolabs, cat. no. R0568S)

- Dpnll restriction endonuclease (New England Biolabs, cat no. R0543S)

- Taq DNA polymerase, provided with PCR buffer (10x) and $\mathrm{MgCl}_{2}$ (25 mM) (New England Biolabs, cat no. M0267S)

- $\quad$ dNTP (10 mM) (New England Biolabs, cat no. N0447S)

- T4 DNA ligase, provided with ligase buffer (10x) (New England Biolabs, cat no. M0202S) 
- Sodium acetate $3 \mathrm{M} \mathrm{pH} 5.5$ (RNase-free) (Invitrogen/Ambion, cat no. AM9740)

- Ethanol (RNase-free) (MERCK, cat no. 108543)

- 100-bp DNA Ladder (Thermo Scientific, cat no. SM0242)

- 100-10.000-bp DNA Ladder (Thermo Scientific, cat no. SM0331)

- Phenol/chloroform/isoamyl alcohol, Roti®-Phenol/C/I (ROTH, cat no. A156.2) ! Caution This is a hazardous chemical. Avoid contact with skin, eyes and airways.

- Chloroform/isoamyl alcohol, Roti®-C/I (ROTH, cat no. X984.2)! Caution This is a hazardous chemical. Avoid contact with skin, eyes and airways.

- 5x TBE buffer, Nuclease-free (Sigma-Aldrich, cat no. 93306)

- TE buffer (Sigma-Aldrich, cat no. 93283)

- QIAqick Gel Extraction kit (Qiagen, cat no. 28706)

- Plasmid Maxi DNA preparation kit (Qiagen, cat no. 12165)

- $\quad$ pGEM-T Vector Systems (Promega, cat no. A3600)

- Transposon plasmids: pT2/BH (http://www.addgene.org/26556/) or pT2/HB (http://www.addgene.org/26557/) are available from Addgene. The pT2RMCE-Venus construct carries an expression cassette of CAGGS promoter and Venus CDNA, flanked by the SB ITRs $^{38,39,48}$.

- Transposase expression plasmid: pCMV(CAT)T7-SB100X (http://www.addgene.org/34879/) is available from Addgene.

- Altrenogest (Regumate, 4 mg/ml) (MSD Tiergesundheit, cat no. 98920) ! Caution Anesthetic agent; avoid exposure, avoid skin contact, wear gloves.

- Pregnant mare's serum gonadotropin (PMSG) (MSD Tiergesundheit, cat no. 020913) ! Caution Anesthetic agent; avoid exposure, avoid skin contact, wear gloves.

- Human chorionic gonadotropin (hCG) (MSD Tiergesundheit, cat no. 020979) ! Caution Anesthetic agent; avoid exposure, avoid skin contact, wear gloves. 
- Stresnil (Azaperon, 40 mg/ml) (WDT das Tierarztunternehmen, cat no. 04451), dose $1 \mathrm{ml} / 40 \mathrm{~kg}$ body weight

- Novacen (Metamizol, 500 mg/ml) (WDT das Tierarztunternehmen, cat no. 21416), dose $1 \mathrm{ml} / 10 \mathrm{~kg}$ body weight

- Ursotamin (Ketamine, $100 \mathrm{mg} / \mathrm{ml}$ ) (Selectavet, cat no. $25 \mathrm{ml}$ ), dose $1 \mathrm{ml} / 10 \mathrm{~kg}$ body weight ! Caution Ketamine anesthesia is only allowed in combination with a sedative (Azaperon) and an analgesic (Novacen)

- Procapen (Benzylpenicillin-procain, 300 mg/ml) (WDT das Tierarztunternehmen, cat no. 23636), dose $1 \mathrm{ml} / 15 \mathrm{~kg}$ body weight

- Mediferan (200 mg/ml) (WDT das Tierarztunternehmen, cat no. 24328), dose $1 \mathrm{ml} /$ piglet

- Oxytocin (10 U/ml) (WDT das Tierarztunternehmen, cat no. 00442), dose 1-4 ml/sow

- Phosphate buffered saline (PBS) (Applichem, cat no. A0964,9050)

- Newborn calf serum (NBCS) (Thermo Scientific, cat no. SH30118.02)

- Fetal calf serum (Thermo Scientific, cat no. SH30084.03)

- $\mathrm{NaCl}$ (Sigma-Aldrich, cat no. S5886-500g)

- $\quad$ LiCl (Merck, cat no. 1.05673.0250)

- Sucrose (Fluka, cat no. 84100-1kg)

- EDTA (Roth, cat no. 8043.1)

- BSA (Sigma-Aldrich, cat no. A7030-10g)

- Na-pyruvate (Applichem, cat no. A3912,0100)

- 2-propanol (Roth, cat no. 6752.2)

- $\quad$ Tris buffer (Roth, cat no. 4855.3)

- $\mathrm{MgCl}_{2} \times 6 \mathrm{H}_{2} \mathrm{O}$ (Roth, cat no. 2189.2)

- HEPES (Roth, cat no. HN781)

- Na-lactate (Sigma-Aldrich, cat no. 71718)

- Penicillin (Applichem, cat no. A1837,0100) 
- Streptomycin (Applichem, cat no. A1852,0250)

- Gentamycin (Roth, cat. no. 0233-2)

- $\mathrm{CaCl}_{2} \times 2 \mathrm{H}_{2} \mathrm{O}$ (Sigma-Aldrich, cat no. C5080)

- $\mathrm{NaH}_{2} \mathrm{PO}_{4}$ (Sigma-Aldrich, cat no. 71507)

- $\mathrm{KCl}$ (Sigma-Aldrich, cat no. P5405)

- $\mathrm{KH}_{2} \mathrm{PO}_{4}$ (Sigma-Aldrich, cat no. 229805)

- $\mathrm{MgSO}_{4} \times 7 \mathrm{H}_{2} \mathrm{O}$ (Sigma-Aldrich, cat no. 63138)

- $\mathrm{NaHCO}_{3}$ (Sigma-Aldrich, cat no. S-4019)

- Ca-lactate x $5 \mathrm{H}_{2} \mathrm{O}$ (Sigma-Aldrich, cat no. C8356)

- L-glutamine (Sigma-Aldrich, cat no. G1251)

- Hypotaurine (Sigma-Aldrich, cat no. H1384)

- Minium essential medium (MEM) (PAA, cat no. E15-832)

- Silicon oil (DL200 fluid) (Serva, cat no. 35135)

- Hyaluronidase (Sigma-Aldrich, cat no. 3506)

- Androhep (Minitube, cat no. 13529/5010)

- Frozen colostrum (50 ml aliquots, derived from sows directly after parturition)

- Milk replacement (Ferkelmilch) (Bewital-agri, cat no. 1110)

- 35-mm Petri dishes (Greiner Bio-One, cat no. 627102)

- 90-mm Petri dishes (Greiner Bio-One, cat no. 632161)

- $10-\mathrm{ml}$ syringe (VWR, cat no. TERUSS-10ES1)

- Quicktip flexitube (Minitube, cat no. 13452/0391)

- Insemination catheter (Minitube, cat no. 17106/5077)

- DH5 alpha bacteria (Lifetechnologies, cat no. 18265017)

\section{EQUIPMENT}

- Refrigerated centrifuge capable of high speed $(12000 \times g)$ (Thermo Scientific, cat no. 75008162) 
- Water bath, $37^{\circ} \mathrm{C}$ (Thermo Scientific, cat no. 2824)

- NanoDrop® ND-2000 Spectrophotometer (Thermo Scientific, cat no. 91-ND-2000)

- Milli-Q Water Purification System (Merck Millipore, cat no. ZRXQ003T0)

- 1.5-mL tubes, free of DNase and RNase (Eppendorf, cat no. 0030123.328)

- Pipette tips, free of DNase and RNase (Eppendorf, cat no. 0030077.504 [0.1- $10 \mu \mathrm{l}$ tips], 0030077.539 [2-20 $\mu \mathrm{ltips}], 0030077.555$ [2-200 $\mu \mathrm{l}$ tips], cat no. 0030077.571 [50-1000 $\mu \mathrm{l}$ tips])

- Thermal cycler capable of temperature increments for touchdown PCR (Thermo Scientific, cat no. TCA0001)

- Electrophoresis apparatus for agarose gels including running chamber, well combs, gel tray and power supply (BioRad, cat no. 164-5050)

- Micromanipulation microscope: Zeiss Axiovert $35 \mathrm{M}$ microscope with differential interference contrast (DIC), 10x oculars and 5x, 10x and 40x objectives and epifluorescence optics

- Eppendorf micromanipulators and injection control (Eppendorf TransferMan and Eppendorf transjector 5246)

- Siliconized glass plate $(7.5 \mathrm{~cm} \times 5.0 \mathrm{~cm})$

- Stereo microscope for zygote collection (Olympus SZ16)

- Needle (injection microcapillary) puller (Sutter Instruments, Model P-87)

- Micro-forge (Bachofer)

- Holding and handling glass pipettes, $90 \times 1.5 \mathrm{~mm}$ (Assistant, cat no. 3005), used as transport pipettes as well as for the preparation of holding pipettes.

- Glass filaments for injection pipette production, borosilicate glass capillaries GC100TF-10, $1.0 \mathrm{~mm}$ O.D. and $0.78 \mathrm{~mm}$ I.D. (Harvard apparatus, cat no. 30-0038)

- Embryo transfer straw, sterile supercristal (IMV, cat no. 005592)

- Stereomicroscope: for imaging of tissue biopsies or fetuses an Olympus SZ16 stereomicroscope with epifluorescence optics, equipped with an appropriate fluorescence filter block (excitation: 450- 
$490 \mathrm{~nm}$, dichroic mirror: $505 \mathrm{~nm}$ and emission: 520-550 nm) for Venus (excitation maximum: 515 $\mathrm{nm}$, emission maximum: $529 \mathrm{~nm}$ ) is used.

- Hemostatic forceps, curved (Lehnecke Tierärztebedarf, cat no. 381-858)

- Hemostatic forceps, straight (World Precision Instruments, cat no. 501715)

- Operating scissor (World Precision Instruments, cat no. 501754)

- Knee-scissor (Lehnecke Tierärztebedarf GmbH, cat no. 783-9103)

- Scalpel handle (Lehnecke Tierärztebedarf, cat no. 371-509)

- Scalpel blades (Lehnecke Tierärztebedarf, cat no. 597-9992)

- Tissue forceps, 6 inch (Roboz, cat no. RS-7561)

- $\quad$ Tissue forceps, 7 inch (Roboz, cat no. RS5270

- Fixation clamps (Bulldog clamps) (Roboz, cat no. RS-7587)

- Artery forceps, Halstead Mosquito with teeth (Lehnecke Tierärztebedarf, cat no. 310-502)

- Artery forceps, Halstead Mosquito (Lehnecke Tierärztebedarf, cat no. 310-498)

- $1 \mathrm{ml}$ syringe (Becton Dickinson, cat no. 309628)

- Cutting needles (Lehnecke Tierärztebedarf, cat no. 442-331)

- Needle holder (Lehnecke Tierärztebedarf, cat no. 424-715)

- Suture material (Lehnecke Tierärztebedarf, cat no. 442-287)

- Fenestrated drape (Lehnecke Tierärztebedarf, cat no. 530-0650)

- Adhesive foil (Lehnecke Tierärztebedarf, cat no. 403-316)

- Surgical clothing for surgeon and sterile assistance (Lehnecke Tierärztebedarf, cat no. 700-862)

- Headgear (Lehnecke Tierärztebedarf, cat no. 371-071)

- Buttoned cannula for flushing of zygotes from isolated oviducts (Lehnecke Tierärztebedarf, cat no. 370-132)

- Portable incubator (Minitube, cat no. 19180/000)

- Ultrasound scanner (WDT das Tierarztunternehmen, cat no. 9300vet)

- Microladder (Eppendorf, cat no. 5242 956.003) 
- Mouth pipette

- Pipette controller (Brand GmbH, cat no. 25900)

- Blue LED flood light, FL24 floodlight spot (Musikhaus Korn, cat no. 2181195)

- Lee emission filter, foil filter (Lee, cat no. 105)

- Electronic camera (e. g., Canon Powershot)

- Video camera

- Insulated thermo container (Gastro24, cat no. 3766400)

\section{REAGENT SETUP}

Hepes+Calcium stock medium. Dissolve $6.6 \mathrm{~g} \mathrm{NaCl}, 0.238 \mathrm{~g} \mathrm{KCl}, 0.294 \mathrm{~g} \mathrm{CaCl}_{2} \times 2 \mathrm{H}_{2} \mathrm{O}, 0.055 \mathrm{~g}$ $\mathrm{NaH}_{2} \mathrm{PO}_{4}, 0.1016 \mathrm{~g} \mathrm{MgCl}_{2} \times 6 \mathrm{H}_{2} \mathrm{O}, 0.168 \mathrm{~g} \mathrm{NaHCO}_{3}, 2.383 \mathrm{~g}$ HEPES, $1.8667 \mathrm{~g}$ Na-lactate, $0.06 \mathrm{~g}$ penicillin $(100 \mathrm{U} / \mathrm{ml})$, and $0.05 \mathrm{~g}$ streptomycin $(50 \mu \mathrm{g} / \mathrm{ml})$ in $900 \mathrm{ml}$ of ultrapure water. Adjust $\mathrm{pH}$ to 7.34, and volume to $1 \mathrm{~L}$ with water. After sterile filtration, store $100 \mathrm{ml}$ aliquots at $4{ }^{\circ} \mathrm{C}$ for up to three months.

$100 \mathrm{mM}$ Na-pyruvate. Dissolve $11 \mathrm{~g} \mathrm{Na-pyruvate} \mathrm{in} 1 \mathrm{~L}$ of ultrapure water to obtain a $100 \mathrm{mM}$ solution. Sterilize by filtration, and store at $4{ }^{\circ} \mathrm{C}$ for up to three months.

Hepes+Calcium working medium. Warm up a $100 \mathrm{ml}$ aliquot of the Hepes+Calcium stock medium to room temperature $\left(21^{\circ} \mathrm{C}\right)$ directly before use, add $250 \mu \mathrm{l}$ of $100 \mathrm{mM}$ Na-pyruvate, $1.056 \mathrm{~g}$ sucrose and $0.4 \mathrm{~g} \mathrm{BSA}$ and dissolve by stirring. The Hepes+Calcium working medium needs to be prepared freshly.

Hyaluronidase stock solution. Dissolve $50 \mathrm{mg}$ hyaluronidase in $1 \mathrm{ml}$ Hepes+Calcium stock medium to obtain a $5 \%$ (wt/vol) stock solution. Store frozen as $50 \mu \mathrm{l}$ aliquots at $-20{ }^{\circ} \mathrm{C}$ for up to 6 months. To obtain a $0.125 \%$ (wt/vol) hyaluronidase working solution, thaw a $50 \mu \mathrm{l}$ aliquot and dilute to $2 \mathrm{ml}$ with Hepes+Calcium working medium. Prepare freshly. 
NBCS solution. Dissolve $1 \mathrm{ml}$ of NBCS in $99 \mathrm{ml}$ sterile PBS. Store frozen in $10 \mathrm{ml}$ aliquots at $-20^{\circ} \mathrm{C}$. Prewarm to $37^{\circ} \mathrm{C}$ before use.

PZM medium. Dissolve $0.63 \mathrm{~g} \mathrm{NaCl}, 0.0746 \mathrm{~g} \mathrm{KCl}, 0.0048 \mathrm{~g} \mathrm{KH}_{2} \mathrm{PO}_{4}, 0.01 \mathrm{~g} \mathrm{MgSO}_{4} \times 7 \mathrm{H}_{2} \mathrm{O}$, $0.2106 \mathrm{~g} \mathrm{NaHCO}_{3}, 0.0022 \mathrm{~g} \mathrm{Na-pyruvate,} 0.0617 \mathrm{~g}$ Ca-lactate $\times 5 \mathrm{H}_{2} \mathrm{O}, 0.0146 \mathrm{~g}$ L-glutamine, 0.0546 $\mathrm{g}$ hypotaurine, $1 \mathrm{ml}$ MEM, $0.005 \mathrm{~g}$ gentamycin and $0.3 \mathrm{~g}$ BSA in a final volume of $100 \mathrm{ml}$ ultrapure Milli-Q water ( $\mathrm{pH}$ 7.3). Sterilize by filtration. Fill 2-3 wells of a 4-well plate with $300 \mu$ l of PZM medium and store in a $39{ }^{\circ} \mathrm{C}$ incubator (atmosphere of $5 \% \mathrm{CO}_{2}$ in air) for 2-3 hours before use.

1 M Tris. Dissolve $121.14 \mathrm{~g}$ Tris in $900 \mathrm{ml}$ ultrapure Milli-Q water. Adjust $\mathrm{pH}$ to 7.5 , and volume to $1 \mathrm{~L}$ with Milli-Q water. Sterilize by autoclaving, and store at room temperature for up to one year.

0.5 M EDTA. Dissolve $186.12 \mathrm{~g}$ EDTA by stirring in ultrapure Milli-Q water, adjust $\mathrm{pH}$ to 8.0 , and fill-up with Milli-Q water to $1 \mathrm{~L}$ to obtain a $0.5 \mathrm{M}$ solution. Sterilize by filtration, and store at room temperature for up to one year.

Injection buffer. Mix $100 \mu \mathrm{l}$ of $1 \mathrm{M}$ Tris pH 7.5, $25 \mu \mathrm{l}$ of $0.5 \mathrm{M}$ EDTA pH 8.0 and $99.875 \mathrm{ml}$ of ultrapure Milli-Q water. Sterilize by filtration, and store frozen $\left(-20^{\circ} \mathrm{C}\right)$ in $1 \mathrm{ml}$ aliquots for up to two years. Thaw an aliquot directly before use.

DNA injection solution. Dilute transposon (transgene) plasmid to $20 \mathrm{ng} / \mu \mathrm{l}$ in $100 \mu \mathrm{l}$ sterile injection buffer. Dilute transposase expression plasmid pCMV(CAT)T7-SB100X to $10 \mathrm{ng} / \mu \mathrm{l}$ in a volume of 100 $\mu$ of injection buffer. Mix both plasmid solutions to obtain $200 \mu$ of injection solution, containing 10 $\mathrm{ng} / \mu \mathrm{l}$ transposon and $5 \mathrm{ng} / \mu \mathrm{l}$ transposase plasmids. 
$\mathrm{NaCl}$ solution for oligonucleotide annealing. Prepare a $500 \mathrm{mM} \mathrm{NaCl}$ stock solution in Milli-Q water, and sterilize by autoclaving or filtration. Prepare the working solution by diluting the stock $10 \mathrm{x}$ in sterile TE buffer. Keep frozen at $-20^{\circ} \mathrm{C}$.

\section{EQUIPMENT SETUP}

Preparation of micropipettes. Prepare the injection micropipettes directly before use, otherwise they may be clogged due to dust contamination. The injection pipettes are made with a micropipette-puller, with the following adjustments: Heat: 910; Pull: 90; Velocity: 90; Time: 115; Pressure: 330.

Alternatively, commercial suppliers of micromanipulation products, such as Eppendorf (Hamburg) may be considered as source of customized injection micropipettes. This may be more cost-effective for laboratories, which have no access to a pipette puller and a micro-forge.

Preparation of holding pipettes. Pull the glass pipettes $(90 \times 1.5 \mathrm{~mm})$ over a flame, break them at around $225 \mu \mathrm{m}$ outer diameter (80 $\mu \mathrm{m}$ inner diameter) employing a micro-forge, and fire-polish the ends. For transportation of zygotes use the holding and handling pipettes connected to a pipette controller or a standard mouth piece.

Micromanipulator. Place the micromanipulation microscope equipped with injection- and holding pipette manipulators on a vibration-damped table. CRITICAL No vibration from the surrounding should be allowed to transmit to the micromanipulation unit.

Surgical devices and surgical clothing. Heat sterilize $\left(160^{\circ} \mathrm{C}, 4 \mathrm{~h}\right)$ surgical devices and autoclave surgical clothing.

\section{PROCEDURE}

Preparation of plasmids for microinjection $\lambda$ TIMING 2-8 weeks 
CRITICAL Plasmids for CPI must be of high purity and should be prepared by good laboratory practices to avoid co-purification of bacterial genomic DNA, RNA or endotoxins. The $260 \mathrm{~nm} / 280 \mathrm{~nm}$ ratio of the purified DNA should be between 1.8-2.0, and the $260 \mathrm{~nm} / 230 \mathrm{~nm}$ ratio should be between 2.2-2.4, otherwise the plasmid DNA should be discarded.

1 Clone your gene of interest between the ITRS of an SB transposon donor plasmid by standard molecular cloning procedures (www.protocol-online.org).

2 Transform plasmids (the transgene-containing plasmid from Step 1 and pCMV(CAT)T7-SB100X) into DH5 alpha bacteria, and isolate DNAs using the Plasmid Maxi kit according to the manufacturer's instructions.

3 Adjust plasmid DNA concentrations to $1 \mu \mathrm{g} / \mu \mathrm{l}$ in a total volume of $100 \mu \mathrm{l}$.

4 Precipitate the plasmids by adding $10 \mu \mathrm{l}(1 / 10$ volume) of $4 \mathrm{M} \mathrm{LiCl}$ and $250 \mu \mathrm{l}$ (2.5 volumes) of 2propanol to $100 \mu \mathrm{l}$ of plasmid solution, mixing, and freezing at $-80{ }^{\circ} \mathrm{C}$ for $1 \mathrm{~h}$.

5 Centrifuge at $12000 \times g$ for 30 minutes at $4{ }^{\circ} \mathrm{C}$, wash the pellet in $70 \%$ (vol/vol) ethanol, discard the ethanol and air-dry at room temperature for 10 minutes.

6 Resuspend the pellet in $100 \mu \mathrm{l}$ ultrapure $\mathrm{H}_{2} \mathrm{O}$ and determine DNA concentration in a NanoDrop® spectrophotometer.

7 Confirm supercoiled conformation and purity of the plasmids by agarose gel electrophoresis (Fig. 2c): digest $4 \mu \mathrm{g}$ of plasmid DNA with a restriction enzyme that is predicted to cut the plasmid only once (www.protocols-online.org) and run the DNA on a $0.7 \%$ (wt/vol) agarose gel. In parallel, load $4 \mu \mathrm{g}$ of undigested plasmid. The undigested plasmid should mainly consist of a supercoiled band and a weak band indicating nicked plasmids. The digested (linearized) plasmid should run at the calculated size. The absence of high molecular weight DNA confirms the lack of contamination of the sample by bacterial genomic DNA (Fig. 2c).

Pause Point Plasmids can be stored at $-20^{\circ} \mathrm{C}$ for up to one year. 


\section{Superovulation of donor sows and flushing of zygotes $\lambda$ TIMING 4 days}

8 Five pre-pubertal (before first heat) donor sows at an age of approximately six months are required. Optionally, if only older animals are available, a 12-14 days pre-treatment with regumate (see surrogate animals, Step 23) is necessary (Fig. 3). Cage the sows individually, and add $4 \mathrm{ml}$ regumate to the morning fodder for 14 days (Fig. 3).

9 Inject the donor sows with 1500 I.U. PMSG intramuscularly (i.m.) one day after completion of regumate feeding or, in case no regumate feeding was required, four days before the calculated insemination time (Fig. 3, day 0) at 9:00.

10 Inject the donor animals with 500 I.U. hCG i.m. at 9:00 three days after the PMSG injection.

11 Check the animals for signs of estrus, such as swollen and reddened vulva one day after hCG injection.

12 Inseminate sows of the donor group with semen ordered from a commercial supplier; alternatively, semen samples can be obtained from trained boars housed at a boar center by the gloved hand technique. Dilute the sperm-rich fraction with prewarmed $\left(37^{\circ} \mathrm{C}\right)$ Androhep (1:1). Determine sperm counts under a microscope with a 100x objective.

13 Dilute semen with Androhep to a final concentration of $10^{8} \mathrm{sperm}$ cells $/ \mathrm{ml}$, and fill a quicktip flexitube with $100 \mathrm{ml}$ of this semen solution.

14 Artificially inseminate the donor sows $24 \mathrm{~h}$ after hCG injection for the first time (Fig. 3) and 8 hours later for the second time, employing a conventional insemination catheter for pigs. Connect the quicktip flexitube to the insemination catheter, and carefully insert the tip of the catheter into the vulva (approximately $50 \mathrm{~cm}$ deep). Fix the tip by a gentle counterclockwise turning, allowing the semen to flow into the uterus.

15 Sacrifice the zygote donor sows $24 \mathrm{~h}$ after the first insemination.

16 Excise the urogenital tract, and transport them to the lab in an insulated thermo container.

17 Dissect the oviducts from the ovaries and uterus (Fig. 4a). 
18 Examine the ovaries and count the ruptured follicles to estimate the number of zygotes in the oviduct (Fig. 4b). About 60-150 zygotes can be expected to be obtained from 5 donors.

\section{? TROUBLESHOOTING}

19 Flush the oviducts from the infundibulum tubae uterinae employing a $10 \mathrm{ml}$ syringe with a buttoned cannula $(\varnothing 1,4 \mathrm{~mm})$ twice with pre-warmed $\left(37^{\circ} \mathrm{C}\right) 1 \%$ (vol/vol) NCBS solution into a Petri dish (Ø $90 \mathrm{~mm})$ (Fig. 4c-e).

20 Repeat the flushing (Step 19) with $10 \mathrm{ml} 1 \%$ (vol/vol) NCBS solution.

21 Screen the collected flushing fluid for the presence of zygotes under a stereomicroscope. Porcine zygotes have a diameter of $120 \mu \mathrm{m}$, are coated with a zona pellucida, and appear darkcolored (Fig. 2a) ${ }^{58}$. Collect the presumptive zygotes with a transport pipette with the help of a pipette controller. Remove remaining cumulus cells by incubation of the zygotes in $0.125 \%$ hyaluronidase for 3-5 $\min$.

22 Transfer intact zygotes (check for the presence of two polar bodies; Fig. 2a, b) in $80 \mu$ droplets of flushing solution covered with silicone oil, and store them at $37^{\circ} \mathrm{C}$ in a humidified atmosphere for up to $1 \mathrm{~h}$. The zygotes are pipetted with a transport pipette connected to a pipette controller. 10-30 zygotes can be expected per donor sow.

\section{Treatment of surrogates $\lambda$ TIMING 18 days}

23 Synchronize the surrogate sows in parallel to the donor sows (Step 8). Add $5 \mathrm{ml}$ regumate to the morning fodder of the sows for 14 days (Fig. 3). As recipients of microinjected zygotes, three sows at the age of eight months are needed. The three animals need to be separated from each other to make certain they all get their individual dose of regumate.

CRITICAL STEP Choose animals that have undergone at least one cycle of natural heat.

24 Inject 1000 I.U. PMSG i.m. per sow one day after the last day of regumate treatment at 9:00. 25 Inject 500 I.U. hCG i.m. three days after the PMSG treatment at 9:00.

26 Check the animals for signs of estrus, such as swollen and reddened vulva one day after hCG treatment. 


\section{Injection of plasmid DNA into zygotes $\lambda$ TIMING 1-3 hours}

27 Immediately before CPI, dilute transgene-transposon and transposase plasmids in sterile injection buffer to a final concentration of $10 \mathrm{ng} / \mu \mathrm{l}$ (transposon) and $5 \mathrm{ng} / \mu \mathrm{l}$ (transposase) (see

\section{Reagent Setup).}

28 For CPI of zygotes (Step 22), place a siliconized glass plate on the microscope table of the micromanipulation microscope.

29 Assemble the left (holding) micromanipulator by connecting the holding pipette with soft tubing to a 1-ml syringe.

30 Back-fill the injection pipette with the plasmid solution prepared in Step 27.

31 Connect the injection pipette to the Eppendorf transjector and fix it on the right (injection) micromanipulator.

32 Add $500 \mu \mathrm{l} 1 \%$ (vol/vol) NCBS on the siliconized glass plate.

33 Break the tip of the injection pipette by moving it quickly against the siliconized glass plate.

34 Heat up the microscope stage to $34^{\circ} \mathrm{C}$. This temperature is recommended to reduce evaporation. Porcine zygotes tolerate this temperature well for short periods ( $\sim 5$ minutes); depending on the skills of the experimenter 5-15 zygotes can be injected within this time.

35 Adjust the holding pipette on the siliconized glass plate in a $500 \mu \mathrm{l}$ droplet of $1 \%$ (vol/vol) NCBS solution.

36 Place up to ten zygotes (from Step 23) with a transport pipette in the $1 \%$ (vol/vol) NCBS drop.

37 Fix one zygote at the tip of the holding pipette (Fig. 2a) by applying gentle suction with the connected 1-ml syringe. Use a 20x magnification.

38 Use the joy stick control of the Eppendorf transjector to move the tip of the injection pipette close to the equatorial zone of the fixed zygote (opposite to the holding pipette). Use $40 x$ magnification. 
39 Push the injection pipette through the zona pellucida and the plasma membrane (Fig. 2a, b).

40 Microinject the plasmid solution (Step 27) directly into the opaque cytoplasm. Apply an injection pressure between 0.5 and $0.8 \mathrm{hPa}$, depending on the opening size of the injection pipette. The injection pressure can be set at the Eppendorf transjector. An estimated volume of 10 picoliter plasmid solution is injected by this procedure.

CRITICAL STEP Change the drop of $1 \%$ (vol/vol) NCBS on the glass plate every 15 minutes to avoid concentration by evaporation.

CRITICAL STEP Change the injection pipette if the tip gets dirty, or clogged with remnants of cytoplasm or cell membrane.

41 After all zygotes of a group have been injected, transfer them to a drop of Hepes+Calcium medium covered with silicone oil, and store them at $39{ }^{\circ} \mathrm{C}$ for up to 3 hours. Typically, the injection of $\sim 90-120$ zygotes will take $2-3$ hours. This step can be completed by 13:00 at the injection day. Check the zygotes 15 minutes before embryo transfer to surrogates sows for signs of lysis - up to $20 \%$ of the injected zygotes may lyse after being injected and are to be discarded. Lysed zygotes show an uneven cell membrane, and cytoplasm may leak out of the injection site.

42 Load each transfer straw with 30-40 zygotes, sufficient for embryo transfer into one recipient. Place only intact zygotes in the transfer straw. Load the transfer straw as follows: medium> air> medium with zygotes > air> medium (Fig. 5).

43 Transport the transfer straws to the surgery room in a portable incubator at $39{ }^{\circ} \mathrm{C}$.

\section{(Optional) Culture of microinjected zygotes $\lambda$ TIMING 30 minutes}

44 Culture 10-30 microinjected embryos in $50 \mu \mathrm{l}$ drops of PZM medium in $35 \mathrm{~mm}$ Petri dishes overlayed with silicone oil at $39{ }^{\circ} \mathrm{C}, 5 \% \mathrm{CO}_{2}$ in order to assess the functionality of a new transgene-transposon construct by fluorescence (in case the transposon has a fluorescent marker in addition to a gene-of-interest). In case of the pT2RMCE-Venus transposon, expression of Venus is expected to start from 4-8 cell stages onwards. 
CRITICAL STEP Porcine embryos require an incubation temperature of $39^{\circ} \mathrm{C}$ and are sensitive to temperature changes. To achieve the best development rates in vitro, dishes with porcine embryos should be left untouched in the incubator during the 5-day period.

45 Assess Venus expression in blastomeres at day 5 of culture with a fluorescence microscope. CRITICAL STEP Expression of the Venus reporter in blastocysts is a good indicator for gene transfer, but alone no proof for SB-catalyzed transposition, as episomal plasmids will also be transcribed ${ }^{54,55}$ To prove integration, embryo transfer to surrogates and the analysis of offspring is recommended.

\section{Embryo transfer (ET) into synchronized surrogates $\lambda$ TIIIING 2 hours}

46 Fasten the surrogate sows at least $12 \mathrm{~h}$ prior to surgery with access to water. Do not feed the surrogates on the day of surgery.

47 Weigh the animals at around 14:00 on the day of microinjection and surgery, to allow calculation of the dose of anesthetics.

48 Treat the sows with Azaperon ( $1 \mathrm{mg} / \mathrm{kg}$ i.m. $=1 \mathrm{ml} / 40 \mathrm{~kg}$ body weight) 45 minutes before surgery.

49 Place a venous access in an ear vein, and anesthesize the sow i.v. with Ursotamin $(10 \mathrm{mg} / \mathrm{kg}=$ $1 \mathrm{ml} / 10 \mathrm{~kg})$ and Metamizol $(50 \mathrm{mg} / \mathrm{kg}=1 \mathrm{ml} / 10 \mathrm{~kg})$.

50 Place and fix the anesthetized animal in a dorsal position on a surgery table.

51 After washing and cleaning the sow, sterilize the skin with $70 \%$ (vol/vol) ethanol.

52 Cover the surgery field with an adhesive foil to ensure sterile conditions.

53 Cut the skin with a scalpel at the linea alba at a length of about $10-12 \mathrm{~cm}$, further handling is done by manual preparation by the surgeon and the sterile assistant wearing sterile surgical gloves.

54 Gently move away the intestines to allow access to one uterus horn.

55 Gently pull out one uterus horn.

56 Examine the connected ovary for the presence of ovulated follicles (Fig. 6a, b). If the ovary contains more than five ovulated follicles, this side is used for embryo transfer. If less than five 
ovulation sites are counted, pull out the other uterus and inspect the ovary. If this ovary also has less than five ovulation sites, the animal is not used for embryo transfer. If five or more ovulated follicles are counted, the embryo transfer is continued.

57 Take out the transfer straw from the portable incubator (Step 43).

58 Carefully insert the soft transfer straw through the infundibulum into the oviduct (Fig. $\mathbf{5 c}, \mathbf{d}$ and Fig. 6b).

59 Flush the embryos into the oviduct by applying slight pressure with a mandrin (Fig. 5d and Fig. 6c). Care has to be taken to avoid injuries to the infundibulum and bleedings.

60 Pull out the transfer straw, and gently place back the uterus horn.

61 Dampen the uterus with $50-100 \mathrm{ml}$ sterile, prewarmed $\left(37^{\circ} \mathrm{C}\right)$ PBS to avoid bonding.

62 Stitch the wound in three layers (Fig. 6d) and cover it with a duct tape.

63 Finally, inject the sow i.m. with Procapen (20 mg/kg), and transport it back into the animal quarter.

64 Examine the animals every hour until they stand up.

Confirming the establishment of a pregnancy $\lambda$ TIMING 30 minutes

65 Starting from day 25 after embryo transfer, inspect the recipient sows by ultrasound (Fig. 6e) for implantation and developing fetuses. Depending on the purpose of the experiment, pregnant recipients can be sacrificed to obtain fetal matter of different developmental stages, or are allowed to give birth.

\section{? TROUBLESHOOTING}

66 Check the surrogates daily for symptoms of natural heat (swollen and reddened vulva), which may indicate that the transferred embryos have been resorbed.

Establishment of transgenic pig lines $\lambda$ TIMING 10-12 months 
CRITICAL Breeding to homozygous transgenic lines often causes inbreeding problems in pigs, such as extreme small litters of 1-3 pups. Therefore, it is advisable to maintain desired transgenes in hemizygous lines.

! Caution All FO animals and all of their offspring are, by definition of the gene law, putative gene modified organisms (GMOS). It has to be ensured that the pigs are maintained in a registered S1animal quarter and that the animals and their fate are documented.

67 Pregnancy and delivery: pregnancy in pigs lasts for 115-117 days. In the last week of gestation, cage the sows individually and inspect them daily for signs of birth, i.e. swelling and reddening of the vulva, and milk production in the mammary glands.

68 Allow the sows to give birth spontaneously, which typically occurs during night time.

\section{? TROUBLESHOOTING}

69 Check sows during delivery, because in case of a small litter size (2-4 piglets) the birth process may stop or may be delayed.

70 If the time interval between delivered piglets is longer than 30 minutes, an i.m. injection of oxytocin (10-30 U/sow) is recommended, otherwise piglets may die in the uterine channel due to suffocation.

71 Check if the afterbirth is coming on time (within the next 16 hours), otherwise another oxytocin treatment is recommended.

72 Control the health status of sow and piglets.

73 If the sow is nervous and did not lie down, an injection (i.m.) of Azaperon $(0.2 \mathrm{mg} / \mathrm{kg}$ ) is recommended. This will calm down the sow, and allow the piglets to suckle colostrum.

CRITICAL STEP It is important that all piglets suck colostrum milk. Small or weak piglets may require hand feeding with colostrum, before they start suckling themselves. Colostrum is important to support the piglets with maternal antibodies as the epitheliochorial organization of the porcine placenta effectively prevents any transfer of antibodies.

74 In case permanent hand feeding is required, keep the piglet(s) in a small box below an infrared warming bulb. 
75 Feed the piglets at $4 \mathrm{~h}$ intervals with $50-200 \mathrm{ml}$ pre-warmed milk replacement (volume depends on age and size). At the age of three weeks they will start grabbing solid pellets.

76 Administer iron injections to all piglets ( $1 \mathrm{ml} /$ animal Mediferan, i.m.) on the second day. 77 For detection of fluorescence, collect the piglets in a small box and transport them into a dimmed room.

CRITICAL To avoid false positive detections and to set up the system it is important to compare transgenic piglets expressing the fluorescent marker with non-transgenic littermates (alternatively, aged-matched wild-type piglets). This allows for the assessment of the amount of scattered and reflected light.

78 Excite with a blue floodlight LED and identify the fluorescent piglets by using goggles with specific emission filters (Fig. 7a, b). Images and videos can be obtained by using an electronic camera equipped with the proper emission filter (Supplementary Video 1).

79 (Optional) Hair phenotyping: collect hair samples for fluorescence analysis under a microscope ${ }^{59}$. In transgenic pigs carrying the CAGGS-Venus transposon, the Venus protein is deposited in the hair and maintains its fluorescent properties. The hair samples can be stored under ambient conditions (e.g. in Petri dishes) without loss of fluorescence for more than 6 months. Genotyping by Southern blotting can be performed to determine the copy number of genomically integrated transposons (Fig. 7c, d $)^{42}$. The expression pattern can be confirmed by Western blotting with a transgene-specific antibody (Fig. 7e, f) ${ }^{59}$.

Genotyping of transgenic animals: Confirming transgene insertions by PCR $\lambda$ TIMING 2.5 hours CRITICAL If the transposon includes a visibly expressed fluorescent marker, early embryos and FO offspring can be identified by fluorescence emission (Steps 77-79, Fig. 7a, b and Supplementary Video 1). However, transgene integration and germline transmission must be confirmed by DNA analysis. 80 Isolate genomic DNA of F0 animals from tail or ear biopsies. A simple and reliable protocol for DNA isolation from tissue samples is available at The Jackson Laboratory page: 
http://jaxmice.jax.org/support/genotyping/tail_phenol.html. Include a positive control (DNA from an established transgenic animal) in the subsequent PCR tests.

81 Set up a PCR reaction in a $25 \mu$ volume containing the following components:

\begin{tabular}{lll}
\hline Component & Amount per reaction & Final \\
\hline PCR buffer (10x) & $2.5 \mu \mathrm{l}$ & $1 \mathrm{x}$ \\
$\mathrm{MgCl}_{2}(25 \mathrm{mM})$ & $1.5 \mu \mathrm{l}$ & $1.5 \mathrm{mM}$ \\
$\mathrm{dNTP}(10 \mathrm{mM})$ & $0.5 \mu \mathrm{l}$ & $0.2 \mathrm{mM}$ \\
Primer SB short $(10 \mathrm{pmol} / \mu \mathrm{l})($ Table 1$)$ & $0.8 \mu \mathrm{l}$ & $8 \mathrm{pmol}$ \\
Primer Tbal rev $(10 \mathrm{pmol} / \mu \mathrm{l})($ Table 1$)$ & $0.8 \mu \mathrm{l}$ & $8 \mathrm{pmol}$ \\
Genomic DNA & $1 \mu \mathrm{l}$ & $\sim 200 \mathrm{ng}$ \\
Taq DNA polymerase & $0.4 \mu \mathrm{l}$ & $2 \mathrm{U}$ \\
$\mathrm{H}_{2} \mathrm{O}$ & $17.5 \mu \mathrm{l}$ & -
\end{tabular}

CRITICAL STEP Include the transgene plasmid DNA in a separate reaction as a positive control for the PCR.

82 Run the PCR reaction using the following conditions:

\begin{tabular}{l|c|c|c|c} 
Cycle number & Denature & Anneal & Extend & Hold \\
\hline 1 & $94^{\circ} \mathrm{C}, 5 \mathrm{~min}$ & & \\
$2-31$ & $94^{\circ} \mathrm{C}, 1 \mathrm{~min}$ & $55^{\circ} \mathrm{C}, 30 \mathrm{~s}$ & $72^{\circ} \mathrm{C}, 30 \mathrm{~s}$ & \\
32 & & & $72^{\circ} \mathrm{C}, 7 \mathrm{~min}$ & \\
33 & & & $4{ }^{\circ} \mathrm{C}$
\end{tabular}

83 Run a $5-\mu$ l aliquot of the PCR product on a $1 \%$ (wt/vol) agarose gel. A PCR product of 201 bp in length indicates the presence of genomically integrated SB transposons. An example result is shown in Supplementary Fig. 1a.

? TROUBLESHOOTING

Identification of individual transgene integrations by ligation-mediated PCR (LMPCR)

$\lambda$ TIIMING

1-2 weeks 
84 Digest $1 \mu \mathrm{g}$ of genomic DNA isolated from F0 animals with Bfal and in a separate reaction $1 \mu \mathrm{g}$ with DpnII (Supplementary Fig. 1b), in $50 \mu$ l volumes. Include a negative control sample (genomic DNA isolated from a non-transgenic animal) as well. Follow the instructions of the enzyme supplier. To reach complete digestion, incubate the reaction for 3 hours at $37^{\circ} \mathrm{C}$.

CRITICAL Always use high quality genomic DNA as template for genotyping PCR. Good quality genomic DNA runs on an agarose gel as a dominant, high molecular weight band (Supplementary Fig. 1c).

85 Add $50 \mu \mathrm{l}$ phenol/chloroform/isoamyl alcohol to each tube. ! Caution This is a hazardous chemical. Avoid contact with skin, eyes and airways.

86 Vortex for $10 \mathrm{~s}$ and leave on the bench for 2 min. Repeat this step 3 times.

87 Centrifuge the samples at $12000 \times g$ for $5 \mathrm{~min}$ at room temperature.

88 Transfer the top layer $(-50 \mu \mathrm{l})$ to a new $1.5 \mathrm{~mL}$ tube, and add $5 \mu \mathrm{l}(1 / 10$ volume $)$ of sodium acetate and $125 \mu \mathrm{l}$ (2.5 volumes) of ethanol, shake well, and let the digested DNA precipitate for $30 \min$ at $-20^{\circ} \mathrm{C}$.

89 Spin down at $12000 \times g$ for $15 \min$ at $4{ }^{\circ} \mathrm{C}$, and discard the supernatant.

CRITICAL STEP The pellet is barely visible. To avoid loss of DNA, remove the liquid using a $200 \mu \mathrm{l}$ pipette tip by touching only the wall of the tube that faced the inner side of the rotor.

90 Wash the pellet in cold $70 \%$ (vol/vol) ethanol. Keep the ethanol on the pellet for $10 \mathrm{~min}$.

91 Spin down at $12000 \times g$ for $15 \min$ at $4{ }^{\circ} \mathrm{C}$, and discard the supernatant.

CRITICAL STEP The pellet is barely visible. To avoid loss of DNA remove the liquid using a $200 \mu$ l pipette tip by touching only the wall of the tube that faced the inner side of the rotor.

92 Air-dry the pellet for 5-10 minutes and resuspend it in $20 \mu$ l sterile Milli-Q water.

93 Measure the concentration of the digested DNA using a a NanoDrop ${ }^{\circledR}$ spectrophotometer. The typical yield is between $30-50 \mathrm{ng} / \mu \mathrm{l}$.

94 To check digestion run 200 ng of each sample on $1 \%$ (wt/vol) agarose gel. The digested samples should run as a smear centered between 0.5-1 kb in size (Supplementary Fig. 1d).

Pause Point The digested genomic DNA samples can be stored at $-20^{\circ} \mathrm{C}$ for up to 1 year. 
95 Prepare the double-stranded linkers by mixing the Linker(+) oligo with the Linker(-)Bfal or with the Linker(-)Dpnll oligo (Table 1) in separate tubes at a final concentration of $10 \mathrm{pmol} / \mu \mathrm{l}$ each in $100 \mu \mathrm{l}$ TE buffer containing $50 \mathrm{mM} \mathrm{NaCl}$

96 Place the tubes containing the oligonucleotide solutions into a boiling water bath for 2 min, switch off heating and leave the tubes in the bath overnight to allow slow cool down and hybridization of the two single-stranded oligonucleotides to form the double-stranded linker.

Pause Point The annealed double-stranded oligonucleotides can be stored at $-20^{\circ} \mathrm{C}$ for up to 1 year.

97 Ligate the Bfal linkers and the Dpnll linkers to the corresponding Bfal- and DpnII-digested genomic DNA samples, respectively (Supplementary Fig. 1b). Set up the ligation reaction containing the components below, and incubate overnight at $16{ }^{\circ} \mathrm{C}$.

\begin{tabular}{lll}
\hline Component & Amount per reaction & Final \\
\hline Ligase buffer (10x) & $5 \mu \mathrm{l}$ & $1 \mathrm{x}$ \\
Bfal- or DpnIl-digested genomic DNA & $\mathrm{X} \mu \mathrm{l}$ & $150 \mathrm{ng}$ \\
Annealed Bfal or Dpnll linker (10 pmol/ $\mu \mathrm{l})$ & $2 \mu \mathrm{l}$ & $20 \mathrm{pmol}$ \\
T4 DNA Ligase & $3 \mu \mathrm{l}$ & $18 \mathrm{U}$ \\
$\mathrm{H}_{2} \mathrm{O}$ & $\mathrm{X} \mu \mathrm{l}$ & to final volume of $50 \mu \mathrm{l}$ \\
\hline
\end{tabular}

98 Set up the $1^{\text {st }} \mathrm{PCR}$ in a $50 \mu$ reaction volume containing the components below:

\begin{tabular}{lll}
\hline Component & Amount per reaction & Final \\
\hline PCR buffer (10x) & $5 \mu \mathrm{l}$ & $1 \mathrm{x}$ \\
$\mathrm{MgCl}_{2}(25 \mathrm{mM})$ & $3 \mu \mathrm{l}$ & $1.5 \mathrm{mM}$ \\
$\mathrm{dNTP}(10 \mathrm{mM})$ & $1 \mu \mathrm{l}$ & $0.2 \mathrm{mM}$ \\
Linker Primer (10 pmol/ $/ \mathrm{ll})($ Table 1$)$ & $1 \mu \mathrm{l}$ & $10 \mathrm{pmol}$ \\
Primer Tbal rev3s $(10 \mathrm{pmol} / \mu \mathrm{l})($ Table 1$)$ & $1 \mu \mathrm{l}$ & $10 \mathrm{pmol}$ \\
Ligated DNA (Step 97) & $2 \mu \mathrm{l}$ & - \\
Taq DNA polymerase & $0.5 \mu \mathrm{l}$ & $2.5 \mathrm{U}$ \\
$\mathrm{H}_{2} \mathrm{O}$ & $36.5 \mu \mathrm{l}$ & - \\
\hline
\end{tabular}


99 Run the $1^{\text {st }} \mathrm{PCR}$ reaction using the following conditions:

\begin{tabular}{l|l|l|l|l} 
Cycle number & Denature & \multicolumn{1}{|c|}{ Anneal } & Extend & Hold \\
\hline 1 & $96{ }^{\circ} \mathrm{C}, 2 \mathrm{~min}$ & & & \\
$2-11$ & $92^{\circ} \mathrm{C}, 40 \mathrm{~s}$ & $60^{\circ} \mathrm{C}-1{ }^{\circ} \mathrm{C} /$ cycle, $40 \mathrm{~s}$ & $72^{\circ} \mathrm{C}, 2 \mathrm{~min}$ & \\
$12-36$ & $92^{\circ} \mathrm{C}, 40 \mathrm{~s}$ & $50^{\circ} \mathrm{C}, 40 \mathrm{~s}$ & $72^{\circ} \mathrm{C}, 1 \mathrm{~min}$ & \\
37 & & & $72^{\circ} \mathrm{C}, 10 \mathrm{~min}$ & \\
38 & & & & $4{ }^{\circ} \mathrm{C}$
\end{tabular}

100 Set up the $2^{\text {nd }}$ PCR in a $50 \mu$ reaction volume containing the components below:

\begin{tabular}{lll}
\hline Component & Amount per reaction & Final \\
\hline $\mathrm{PCR}_{\text {buffer }(10 \mathrm{x})}$ & $5 \mu \mathrm{l}$ & $1 \mathrm{x}$ \\
$\mathrm{MgCl}_{2}(25 \mathrm{mM})$ & $3 \mu \mathrm{l}$ & $1.5 \mathrm{mM}$ \\
dNTP $(10 \mathrm{mM})$ & $1 \mu \mathrm{l}$ & $0.2 \mathrm{mM}$ \\
Nested Primer $(10 \mathrm{pmol} / \mu \mathrm{l})($ Table 1$)$ & $1 \mu \mathrm{l}$ & $10 \mathrm{pmol}$ \\
Primer Tbal $(10 \mathrm{pmol} / \mu \mathrm{l})($ Table 1$)$ & $1 \mu \mathrm{l}$ & $10 \mathrm{pmol}$ \\
$100 x$ diluted $1{ }^{\text {st }} \mathrm{PCR}$ sample & $1 \mu \mathrm{l}$ & - \\
$\mathrm{Taq}$ DNA polymerase & $0.5 \mu \mathrm{l}$ & $2.5 \mathrm{U}$ \\
$\mathrm{H}_{2} \mathrm{O}$ & $37.5 \mu \mathrm{l}$ & - \\
\hline
\end{tabular}

101 Run the $2^{\text {nd }} P C R$ reaction using the following conditions:

\begin{tabular}{l|l|l|c|c} 
Cycle number & Denature & Anneal & Extend & Hold \\
\hline 1 & $96{ }^{\circ} \mathrm{C}, 2 \mathrm{~min}$ & & \\
$2-7$ & $92^{\circ} \mathrm{C}, 40 \mathrm{~s}$ & $66^{\circ} \mathrm{C}-1^{\circ} \mathrm{C} /$ cycle, $40 \mathrm{~s}$ & $72^{\circ} \mathrm{C}, 1 \mathrm{~min}$ & \\
$8-21$ & $92^{\circ} \mathrm{C}, 40 \mathrm{~s}$ & $59^{\circ} \mathrm{C}, 40 \mathrm{~s}$ & $72^{\circ} \mathrm{C}, 1 \mathrm{~min}$ & \\
22 & & & $72^{\circ} \mathrm{C}, 10 \mathrm{~min}$ & \\
23 & & & & \\
& & & &
\end{tabular}

102 Run a $10-\mu l$ aliquot of the PCR product on a $1 \%$ (wt/vol) agarose gel. An example result is shown in Supplementary Fig. 1e. Each band represents a transposon (transgene) genomic integration.

? TROUBLESHOOTING 
103 If strong, distinct bands are visible, isolate them from the gel using the QIAquick Gel Extraction Kit according to the manufacturer's instructions, and sequence them. Multiple bands often represent multiple insertions, and lower intensity bands may represent mosaic integrations, all of which need to be isolated from the gel, subcloned and sequenced. One should be able to identify the TA target dinucleotides immediately flanking the ITR in the genomic sequence, the Bfal and/or Dpnll recognition sites and the linkers that had been ligated to the DNA ends. The PCR amplifications applied in parallel on the Bfal- and Dpnll-digested DNA methods help the user to recover all integrations.

104 Map the insertion sites by a BLAT or BLAST search of the DNA sequence directly flanking the transposon, at the UCSC Genome Bioinformatics website (http://genome.ucsc.edu/cgibin/hgBlat) or at the NCBI website (http://blast.ncbi.nlm.nih.gov/Blast.cgi).

\section{Tracking individual transgene integrations by locus-specific PCR $\lambda$ TIMING 1 week}

105 Design primers matching the integration loci mapped in the founder animals (Step 104). Avoid designing primers that would bind to repetitive elements and thus amplify non-specific PCR products. The BLAT search at the UCSC Genome Bioinformatics website directly provides a RepeatMasker annotation of the genomic loci where the SB transposons have integrated. When using BLAST at the NCBI website select "map viewer" for a given BLAST hit, then select "maps \& options" and choose "repeats" to see the RepeatMasker annotation. After identification of a genomic region free of repetitive sequences in the neighborhood of the SB ITR, design the locus-specific primer so that its $T_{m}$ is between $55-60{ }^{\circ} \mathrm{C}$ and its length is between $20-25$ nucleotides. Run a BLAT or BLAST search with the new primer sequences to make sure that they do not bind to other genomic locations. In addition, general rules for PCR primer design can be found for example at http://www.premierbiosoft.com/tech_notes/PCR_Primer_Design.html. 106 Perfom the locus-specific PCR with the primer designed in Step 105 and primer Tbal (Table 1) to trace specific transgene integrations by the presence or absence of an amplified product. To maximize specificity of primer annealing to the genomic target, the use of touchdown PCR is 
recommended consisting of 5-10 touchdown cycles stepwise decreasing the annealing

temperature by $1{ }^{\circ} \mathrm{C}$ per cycle down to the final annealing temperature, at about $2{ }^{\circ} \mathrm{C}$ below the $\mathrm{T}_{\mathrm{m}}$ of the lower $\mathrm{T}_{\mathrm{m}}$ primer, and 25 additional standard cycles. Supplementary Fig. 2 shows an example of locus-specific PCR test of a rat founder and its F1 descendants.

\section{? TROUBLESHOOTING}

Troubleshooting advice can be found in Table 2.

[Table 1 is in the bottom of the manuscript.]

Table 2| Troubleshooting table.

\begin{tabular}{|c|c|c|c|}
\hline Step & Problem & Possible reason & Possible solution \\
\hline Step 18 & $\begin{array}{l}\text { Poor superovulation } \\
\text { results: no or only } \\
\text { few (<10 per donor) } \\
\text { zygotes obtained }\end{array}$ & Bad sperm quality. & $\begin{array}{l}\text { Age of sows is important for } \\
\text { success of hormonal } \\
\text { synchronization and } \\
\text { superovulation. The donor sow for } \\
\text { zygote production should be pre- } \\
\text { pubertal ( } 6 \text { months of age). } \\
\text { Check sows for heat signals, red } \\
\text { swollen vagina and immobile } \\
\text { standing after stimulating the sow } \\
\text { in the back, or else } \\
\text { synchronization did not work. } \\
\text { The recipients for embryo transfer } \\
\text { should have undergone 1-2 } \\
\text { cycles of natural estrus and be } 7- \\
9 \text { months old. } \\
\text { Sperm quality should be checked } \\
\text { by microscopic analysis. More } \\
\text { than } 50 \% \text { (better }>80 \%) \text { of } \\
\text { spermatozoa should be motile, } \\
\text { and the ejaculate should be free } \\
\text { of blood and bacteria. A regular } \\
\text { semen collection twice per week } \\
\text { may improve the semen quality. } \\
\text { In case of bacterial } \\
\text { contamination, an antibiotic } \\
\text { treatment of the boar is required. }\end{array}$ \\
\hline Step 65 & $\begin{array}{l}\text { No implanted } \\
\text { embryos at day } 25 \\
\text { post-embryo } \\
\text { transfer. }\end{array}$ & $\begin{array}{l}\text { Decreased viability of the injected } \\
\text { zygotes may be due to high } \\
\text { amount of bacterial DNA due to } \\
\text { improper plasmid purification } \\
\text { (Steps 3-7), or the presence of } \\
\text { endotoxins in the injection } \\
\text { mixture. }\end{array}$ & $\begin{array}{l}\text { Check plasmids by gel } \\
\text { electrophoresis for the presence } \\
\text { of bacterial DNA by loading at } \\
\text { least } 4 \mu \mathrm{g} \text { of plasmid DNA in one } \\
\text { lane. If DNA of high molecular } \\
\text { weight ( }>30 \mathrm{~kb} \text { ) is detectable, } \\
\text { prepare a new batch of plasmid. }\end{array}$ \\
\hline
\end{tabular}




\begin{tabular}{|c|c|c|c|}
\hline Step 68 & No offspring. & Failure of implantation. & $\begin{array}{l}\text { If the ultrasound analysis at day } \\
25 \text { post-embryo transfer indicates } \\
\text { the establishment of a pregnancy, } \\
\text { yet no offspring are delivered at } \\
\text { term, it may be worthwhile to } \\
\text { sacrifice a recipient around day } \\
25 \text { of gestation and to analyze the } \\
\text { implantation sites and fetuses. } \\
\text { Normally developed implantation } \\
\text { should have an outer diameter of } \\
\text { about } 10 \mathrm{~cm} \text {, a normal embryo } \\
\text { should be about } 1.8 \mathrm{~cm} \text { in length, } \\
\text { and inner organs and extremities } \\
\text { are already developed (e. g., } \\
\text { heart beating can be detected if } \\
\text { intact embryos are observed } \\
\text { under a stereo microscope). }\end{array}$ \\
\hline Step 83 & $\begin{array}{l}\text { Low frequency of } \\
\text { transgenic founders } \\
\text { per born litter }\end{array}$ & $\begin{array}{l}\text { Larger transgenes may cause a } \\
\text { drop of transgenic rates. } \\
\text { Apparent low transgenic rates } \\
\text { may be due to transgene } \\
\text { detection problems, e. g., } \\
\text { because the genomic DNA } \\
\text { template used in the PCR tests is } \\
\text { degraded. }\end{array}$ & $\begin{array}{l}\text { Increasing the amount of } \\
\text { transposon donor plasmid (up to } \\
20 \mathrm{ng} / \mu \mathrm{l} \text { ) in the final injection } \\
\text { mixture may help to increase the } \\
\text { efficiency in case of larger } \\
\text { transgenes. } \\
\text { Always use high-quality genomic } \\
\text { DNA for PCR. } \\
\text { Include a positive control (DNA } \\
\text { from an established transgenic } \\
\text { animal) in the PCR tests. }\end{array}$ \\
\hline
\end{tabular}

\section{TIMING}

Steps 1-7, preparation of plasmids for microinjection: 2-8 weeks

Steps 8-22, superovulation of donor sows and flushing of zygotes: 4 days

Steps 23-26, treatment of surrogates: 18 days

Steps 27-43, injection of plasmid DNA into zygotes: 1-3 hours

Steps 44-45, culture of microinjected zygotes: 30 min-5 days

Steps 46-64, embryo transfer into synchronized surrogates: 2 hours

Steps 65-66, confirming the establishment of a pregnancy: 30 min

Steps 67-79, establishment of transgenic pig lines: 10-12 months

Steps 80-83, genotyping of transgenic animals: Confirming transgene insertions by PCR: 2.5 hours

Steps 84-104, identification of individual transgene integration events by LMPCR: 1-2 weeks

Steps 105-106, tracking individual transgene integrations by locus specific PCR: 1 week 


\section{Anticipated results}

The co-injection of Sleeping Beauty transposon plasmids into the cytoplasm of porcine zygotes is expected to result in 40-60 \% germline transgenesis per born piglet. This corresponds to the generation of transgenic founders at a frequency of $6-8 \%$ per microinjected zygote. As the developmental competence of porcine zygotes is not or only minimally affected by the cytoplasmic injection, it is sufficient to transfer about 30 embryos per recipient sow, thus allowing for the reduction in the number of animals used. Cytoplasmic injection avoids high-speed centrifugation of opaque zygotes $^{5,54}$, which is necessary when using pronuclear injection, and it avoids invasive removal of metaphase plates from oocytes, which is an essential step of porcine SCNT. The majority of transgene integration events represent specific transpositions of monomeric transposon units (Supplementary Fig. 1c), and the majority of founders will carry 1-3 transposon copies ${ }^{42}$. Crossbreeding of two lines of transposon-transgenic pigs (each with 3 monomeric transposons) resulted in piglets carrying up to five Venus-transposons; these pups showed transposon copy numberdependent fluorescence intensity (Supplementary Video 1). In the present protocol, extra sows are used to produce zygotes. In the future, the use of zygotes derived from in vitro fertilization may result in a further reduction of use of experimental animals.

\section{Statement of responsibility}

Design of study: W.A. Kues, T. Rülicke, M. Pravenec, A. Geurts, Z. Ivics, Z. Izsvak

Performance of experiments: W. Garrels, L. Mates, T.Y. Yau, S. Bashir, V. Zidek, V. Landa, A. Geurts, Z. Ivics, W.A. Kues

Evaluation of data: W.A. Kues, Z. Ivics, W. Garrels

Writing of manuscript: W.A. Kues, Z. Ivics, T. Rülicke, W. Garrels, Z. Izsvak,

\section{Declaration}

The authors declare no competing financial interests. 


\section{Acknowledgements}

Financial support by grants of the Deutsche Forschungsgemeinschaft to W.A.K. and Z.IV. is gratefully acknowledged (KU 1586/2-1 and IV 21/6-1). The expert support and critical input by J.W. Carnwarth, S. Holler, B. Barg-Kues, N. Cleve, M. Ziegler, and M. Diederich are gratefully acknowledged. Whole animal images under fluorescence excitation were done by D.B., the video was recorded by P. Köhler.

\section{REFERENCES}

1. Kuzmuk, K.N. \& Schook, L.B. Pigs as a model for biomedical sciences. in The genetics of the pig, Vol. 2 (eds. Rothschild, M.F. \& Ruvinsky, A.) 426-444 (CAB International, Wallingford, UK, 2011).

2. $\quad$ Kues, W.A. \& Niemann, H. Advances in farm animal transgenesis. Prev Vet Med 102, 146-56 (2011).

3. Whyte, J.J. \& Prather, R.S. Genetic modifications of pigs for medicine and agriculture. Mol Reprod Dev 78, 879-91 (2011).

4. Cibelli, J. et al. Strategies for improving animal models for regenerative medicine. Cell Stem Cell 12, 271-4 (2013).

5. Garrels, W., Ivics, Z. \& Kues, W.A. Precision genetic engineering in large mammals. Trends Biotechnol 30, 386-93 (2012).

6. Petters, R.M. et al. Genetically engineered large animal model for studying cone photoreceptor survival and degeneration in retinitis pigmentosa. Nat Biotechnol 15, 965-70 (1997).

7. Rogers, C.S. et al. Disruption of the CFTR gene produces a model of cystic fibrosis in newborn pigs. Science 321, 1837-41 (2008).

8. Kragh, P.M. et al. Hemizygous minipigs produced by random gene insertion and handmade cloning express the Alzheimer's disease-causing dominant mutation APPsw. Transgenic Res 18, 545-58 (2009).

9. Yang, D. et al. Expression of Huntington's disease protein results in apoptotic neurons in the brains of cloned transgenic pigs. Hum Mol Genet 19, 3983-94 (2010).

10. Flisikowska, T. et al. A porcine model of familial adenomatous polyposis. Gastroenterology 143, 1173-5 e1-7 (2012).

11. Suzuki, S. et al. Il2rg gene-targeted severe combined immunodeficiency pigs. Cell Stem Cell 10, 753-8 (2012).

12. Yeom, H.J. et al. Generation and characterization of human heme oxygenase- 1 transgenic pigs. PLoS One 7, e46646 (2012).

13. Hofmann, A. et al. Epigenetic regulation of lentiviral transgene vectors in a large animal model. Mol Ther 13, 59-66 (2006).

14. Kues, W.A. et al. Epigenetic silencing and tissue independent expression of a novel tetracycline inducible system in double-transgenic pigs. FASEB J 20, 1200-2 (2006).

15. Hall, V.J. Early development of the porcine embryo: the importance of cell signalling in development of pluripotent cell lines. Reprod Fertil Dev 25, 94-102 (2012).

16. Esteban, M.A. et al. Generation of induced pluripotent stem cell lines from Tibetan miniature pig. J Biol Chem 284, 17634-40 (2009). 
17. Ezashi, T. et al. Derivation of induced pluripotent stem cells from pig somatic cells. Proc Natl Acad Sci U S A 106, 10993-8 (2009).

18. Wu, Z. et al. Generation of pig induced pluripotent stem cells with a drug-inducible system. $J$ Mol Cell Biol 1, 46-54 (2009).

19. Kues, W.A. et al. Derivation and characterization of sleeping beauty transposon-mediated porcine induced pluripotent stem cells. Stem Cells Dev 22, 124-35 (2013).

20. Montserrat, N. et al. Generation of pig iPS cells: a model for cell therapy. J Cardiovasc Transl Res 4, 121-30 (2011).

21. West, F.D. et al. Brief report: chimeric pigs produced from induced pluripotent stem cells demonstrate germline transmission and no evidence of tumor formation in young pigs. Stem Cells 29, 1640-3 (2011).

22. Fujishiro, S.H. et al. Generation of naive-like porcine-induced pluripotent stem cells capable of contributing to embryonic and fetal development. Stem Cells Dev 22, 473-82 (2013).

23. Fan, N. et al. Piglets cloned from induced pluripotent stem cells. Cell Res 23, 162-6 (2013).

24. Hofmann, A. et al. Efficient transgenesis in farm animals by lentiviral vectors. EMBO Rep 4, 1054-60 (2003).

25. Whitelaw, C.B. et al. Efficient generation of transgenic pigs using equine infectious anaemia virus (EIAV) derived vector. FEBS Lett 571, 233-6 (2004).

26. Kurome, M. et al. Effects of sperm pretreatment on efficiency of ICSI-mediated gene transfer in pigs. J Reprod Dev 53, 1217-26 (2007).

27. Watanabe, M. et al. The creation of transgenic pigs expressing human proteins using BACderived, full-length genes and intracytoplasmic sperm injection-mediated gene transfer.

Transgenic Res 21, 605-18 (2012).

28. Ivics, Z., Hackett, P.B., Plasterk, R.H. \& Izsvak, Z. Molecular reconstruction of Sleeping Beauty, a Tc1-like transposon from fish, and its transposition in human cells. Cell 91, 501-10 (1997).

29. Ivics, Z. et al. Transposon-mediated genome manipulation in vertebrates. Nat Methods 6, 41522 (2009).

30. Zayed, H., Izsvak, Z., Walisko, O. \& Ivics, Z. Development of hyperactive sleeping beauty transposon vectors by mutational analysis. Mol Ther 9, 292-304 (2004).

31. Rostovskaya, M. et al. Transposon-mediated BAC transgenesis in human ES cells. Nucleic Acids Res 40, e150 (2012).

32. Voigt, K. et al. Retargeting sleeping beauty transposon insertions by engineered zinc finger DNA-binding domains. Mol Ther 20, 1852-62 (2012).

33. Moldt, B. et al. Comparative genomic integration profiling of Sleeping Beauty transposons mobilized with high efficacy from integrase-defective lentiviral vectors in primary human cells. Mol Ther 19, 1499-510 (2011).

34. Grabundzija, I. et al. Comparative analysis of transposable element vector systems in human cells. Mol Ther 18, 1200-9 (2010).

35. Ammar, I. et al. Retargeting transposon insertions by the adeno-associated virus Rep protein. Nucleic Acids Res 40, 6693-712 (2012).

36. Ivics, Z. \& Izsvak, Z. The expanding universe of transposon technologies for gene and cell engineering. Mob DNA 1, 25 (2010).

37. Ammar, I., Izsvak, Z. \& Ivics, Z. The Sleeping Beauty transposon toolbox. Methods Mol Biol 859, 229-40 (2012).

38. Mates, L. et al. Molecular evolution of a novel hyperactive Sleeping Beauty transposase enables robust stable gene transfer in vertebrates. Nat Genet 41, 753-61 (2009).

39. Katter, K. et al. Transposon-mediated transgenesis, transgenic rescue, and tissue-specific gene expression in rodents and rabbits. FASEB J 27, 930-41 (2013). 
40. Ivics, Z. et al. Germline Transgenesis in Rodents by Pronuclear Microinjection of Sleeping Beauty Transposons. Nature Protocols in press (2014).

[CE: references 40 and 41 are sister protocols and will be published by us along with this protocol.]

41. Ivics, Z. et al. Germline Transgenesis in Rabbits by Pronuclear Microinjection of Sleeping Beauty Transposons. Nature Protocols in press (2014).

42. Garrels, W. et al. Germline transgenic pigs by Sleeping Beauty transposition in porcine zygotes and targeted integration in the pig genome. PLoS One 6, e23573 (2011).

43. Ellis, J. Silencing and variegation of gammaretrovirus and lentivirus vectors. Hum Gene Ther 16, 1241-6 (2005).

44. Jahner, D. et al. De novo methylation and expression of retroviral genomes during mouse embryogenesis. Nature 298, 623-8 (1982).

45. Wolf, D. \& Goff, S.P. Embryonic stem cells use ZFP809 to silence retroviral DNAs. Nature 458, 1201-4 (2009).

46. Park, F. Lentiviral vectors: are they the future of animal transgenesis? Physiol Genomics 31, 159-73 (2007).

47. Turan, S. \& Bode, J. Site-specific recombinases: from tag-and-target- to tag-and-exchangebased genomic modifications. FASEB J 25, 4088-107 (2011).

48. Garrels, W. et al. Genotype-independent transmission of transgenic fluorophore protein by boar spermatozoa. PLoS One 6, e27563 (2011).

49. Claeys Bouuaert, C., Lipkow, K., Andrews, S.S., Liu, D. \& Chalmers, R. The autoregulation of a eukaryotic DNA transposon. Elife 2, e00668 (2013).

50. Jakobsen, J.E. et al. Pig transgenesis by Sleeping Beauty DNA transposition. Transgenic Res 20, 533-45 (2011).

51. Carlson, D.F. et al. Strategies for selection marker-free swine transgenesis using the Sleeping Beauty transposon system. Transgenic Res 20, 1125-37 (2011).

52. Al-Mashhadi, R.H. et al. Familial hypercholesterolemia and atherosclerosis in cloned minipigs created by DNA transposition of a human PCSK9 gain-of-function mutant. Sci Transl Med 5, 166ra1 (2013).

53. Wu, Z. et al. Pig transgenesis by piggyBac transposition in combination with somatic cell nuclear transfer. Transgenic Res (2013).

54. Iqbal, K. et al. Cytoplasmic injection of circular plasmids allows targeted expression in mammalian embryos. Biotechniques 47, 959-68 (2009).

55. Iqbal, K. et al. Species-specific telomere length differences between blastocyst cell compartments and ectopic telomere extension in early bovine embryos by human telomerase reverse transcriptase. Biol Reprod 84, 723-33 (2011).

56. O'Malley, R.C., Alonso, J.M., Kim, C.J., Leisse, T.J. \& Ecker, J.R. An adapter ligationmediated PCR method for high-throughput mapping of T-DNA inserts in the Arabidopsis genome. Nat Protoc 2, 2910-7 (2007).

57. Ivics, Z., Izsvak, Z., Medrano, G., Chapman, K.M. \& Hamra, F.K. Sleeping Beauty transposon mutagenesis in rat spermatogonial stem cells. Nat Protoc 6, 1521-35 (2011).

58. Hyttel, P., Sinowatz, F., Vejlsted, M. \& Betteridge, K. Essentials of Domestic Animal Embryology, (Saunders Elsevier, Edinburgh, London, New York, Oxford, Philadephia, St. Louis, Sydney, Toronto, 2010).

59. Garrels, W., Cleve, N., Niemann, H. \& Kues, W.A. Rapid non-invasive genotyping of reporter transgenic mammals. Biotechniques 0, 1-4 (2012). 


\section{FIGURE LEGENDS}

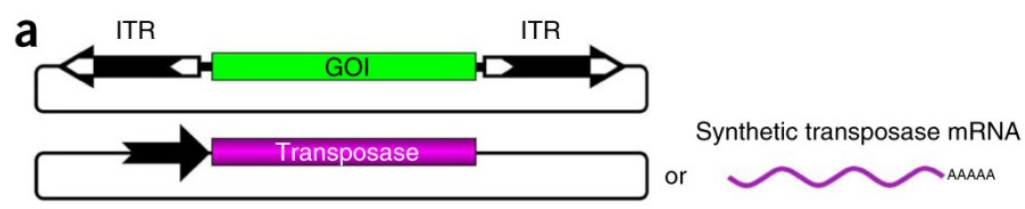

b

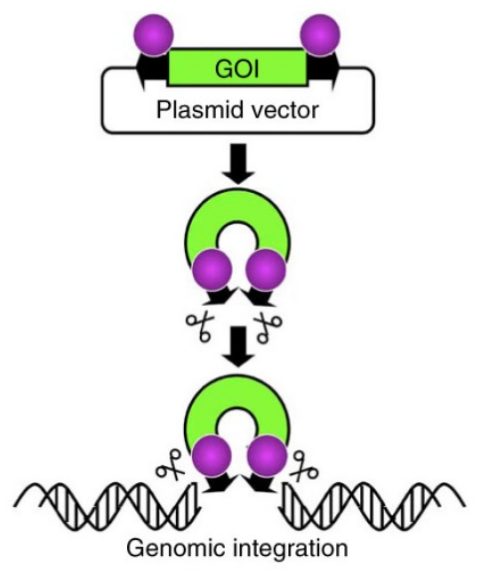

Figure 1. Application of Sleeping Beauty transposons for gene delivery. (a) A bi-component transposon system for delivering transgenes in plasmids. One component contains a gene of interest (GOI) cloned between the transposon inverted terminal repeats (ITR, black arrows) encoded by a plasmid. The other component is either a transposase expression plasmid, or synthetic mRNA encoding the transposase. (b) The transposon carrying a GOI is excised from the donor plasmid and is integrated at a chromosomal site by the transposase (purple spheres). 

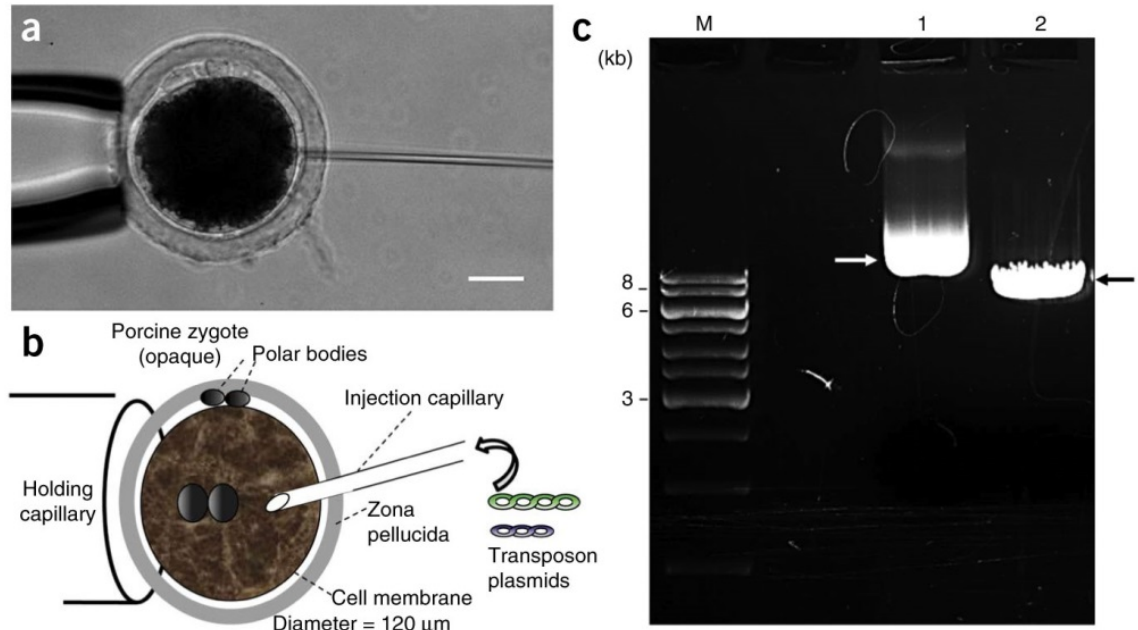

Figure 2. Injection of circular transposon plasmids into the cytoplasm of porcine zygotes. (a) In opaque porcine zygotes the pronuclei are not discernible. The mixture of SB100X the transposase and transgene-transposon plasmids is "blindly" deposited in the cytoplasm. (b) Schematic drawing of CPI into a porcine zygote. (c) Gel electrophoretic analysis of a plasmid sample for supercoiled conformation and purity; M) DNA ladder; 1) non-treated plasmid samples; 2) linearized plasmid sample. The plasmid samples are "overloaded" ( $4 \mu \mathrm{g}$ per lane) to check for the absence of contaminating bacterial genomic DNA. 


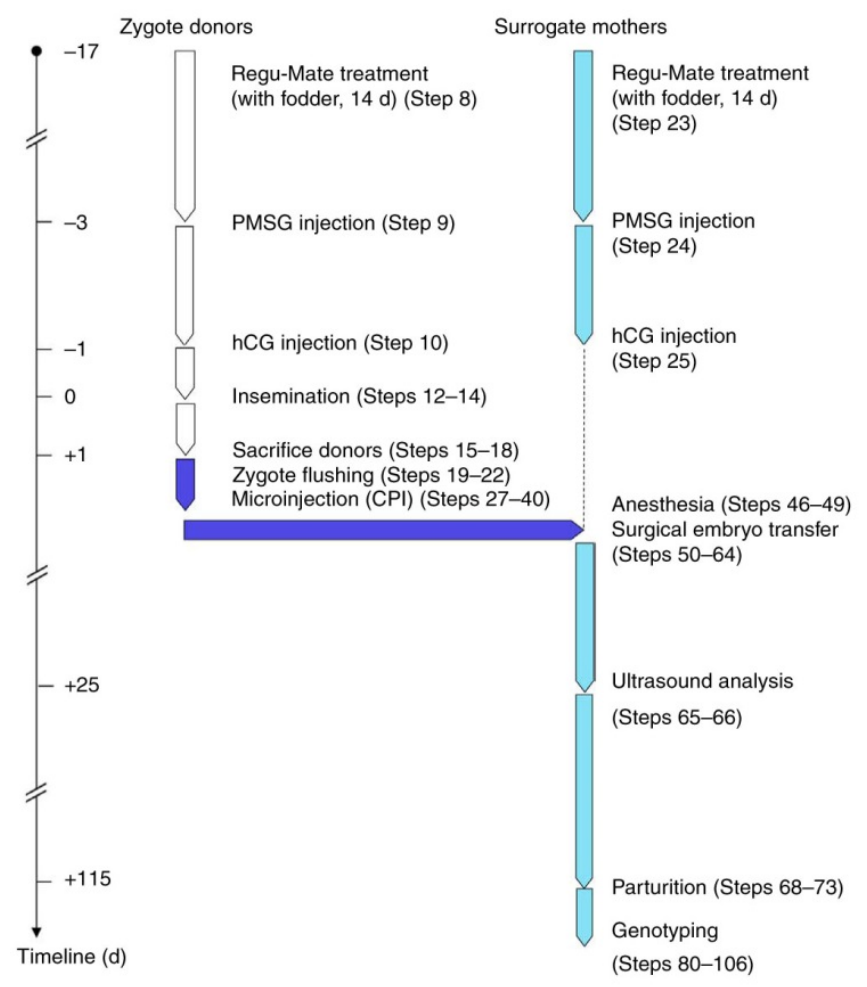

Figure 3. Timeline flowchart for animal treatment and cytoplasmic injection. Timelines for parallel treatment of donor (white arrows) and surrogate animals (light blue arrows) are shown. The timepoint of insemination of donor animals is day 0 . Donor animals are sacrificed on day 1 , the isolated zygotes are microinjected with plasmid DNA and transferred to recipient animals on the same day. Purple arrows indicate steps of in vitro handling. 


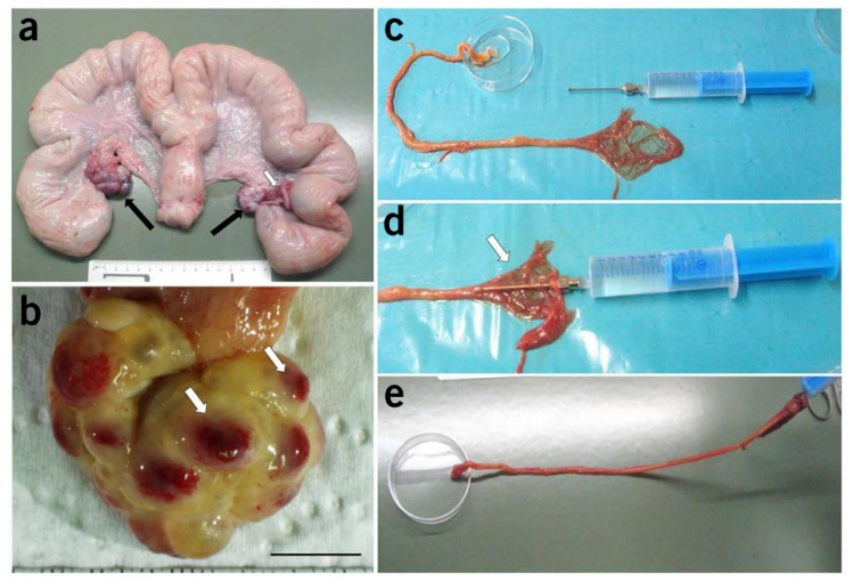

Figure 4. Isolation of porcine zygotes from the oviduct. (a) Uterine tract of an artificially inseminated sow. Black arrows, ovaries; white arrow, oviduct. (b) Isolated porcine ovary at high magnification. Ruptured follicles (some are labeled with white arrows) indicate the number of ovulated oocytes. (c) Porcine oviduct with outspread infundibulum. (d) A buttoned cannula is inserted into the infundibulum. (e) The oviduct is flushed with $10 \mathrm{ml}$ pre-warmed NBCS solution. The flushing medium is collected in a plastic dish. Animal experiments were carried out under the appropriate institutional regulatory board permission.

a

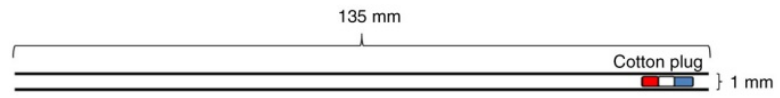

b
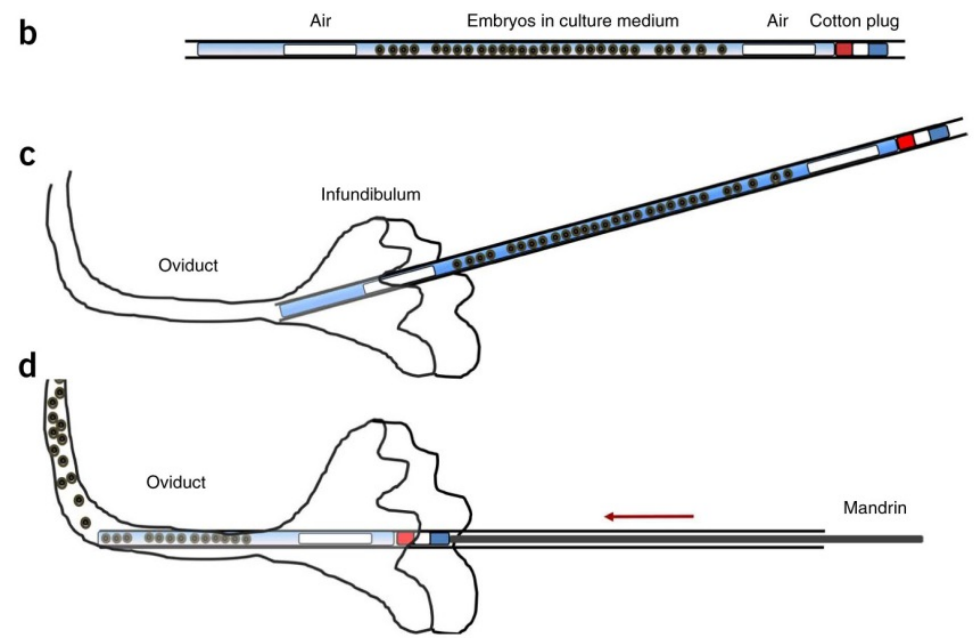

Figure 5. Loading of transfer straw with embryos and embryo transfer. (a) An empty transfer straw, one end is closed by a colored cotton plug. (b) The transfer straw is connected to a pipette 
controller and loaded in the following order: medium, air bubble, medium with zygotes, air bubble, medium. (c) For embryo transfer the transfer straw is inserted through the infundibulum into the (d) oviduct. The embryos are then flushed into the oviduct by pressing the cotton plug slowly forward with a mandrin.

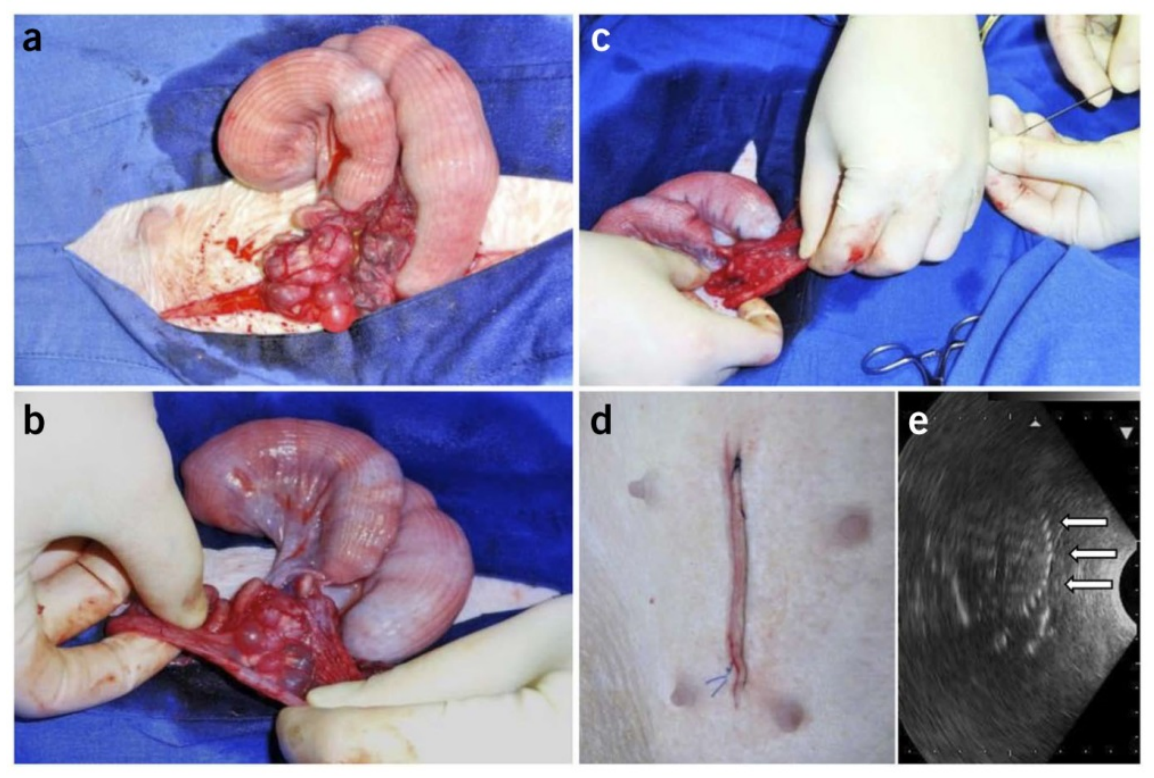

Figure 6. Embryo transfer of microinjected zygotes to synchronized surrogates. (a) The anesthetized recipient is placed in dorsal position on a surgery table. One uterus horn is pulled out. (b) An embryo transfer straw, containing 30-40 treated zygotes, is inserted into the infundibulum. (c) The embryos are flushed into the oviduct. (d) A stitched surgery wound. (e) Ultrasound image obtained from a pregnant recipient at day 60 post-embryo transfer. The backbone of one fetus is in focus (white arrows). Animal experiments were carried out under the appropriate institutional regulatory board permission. 

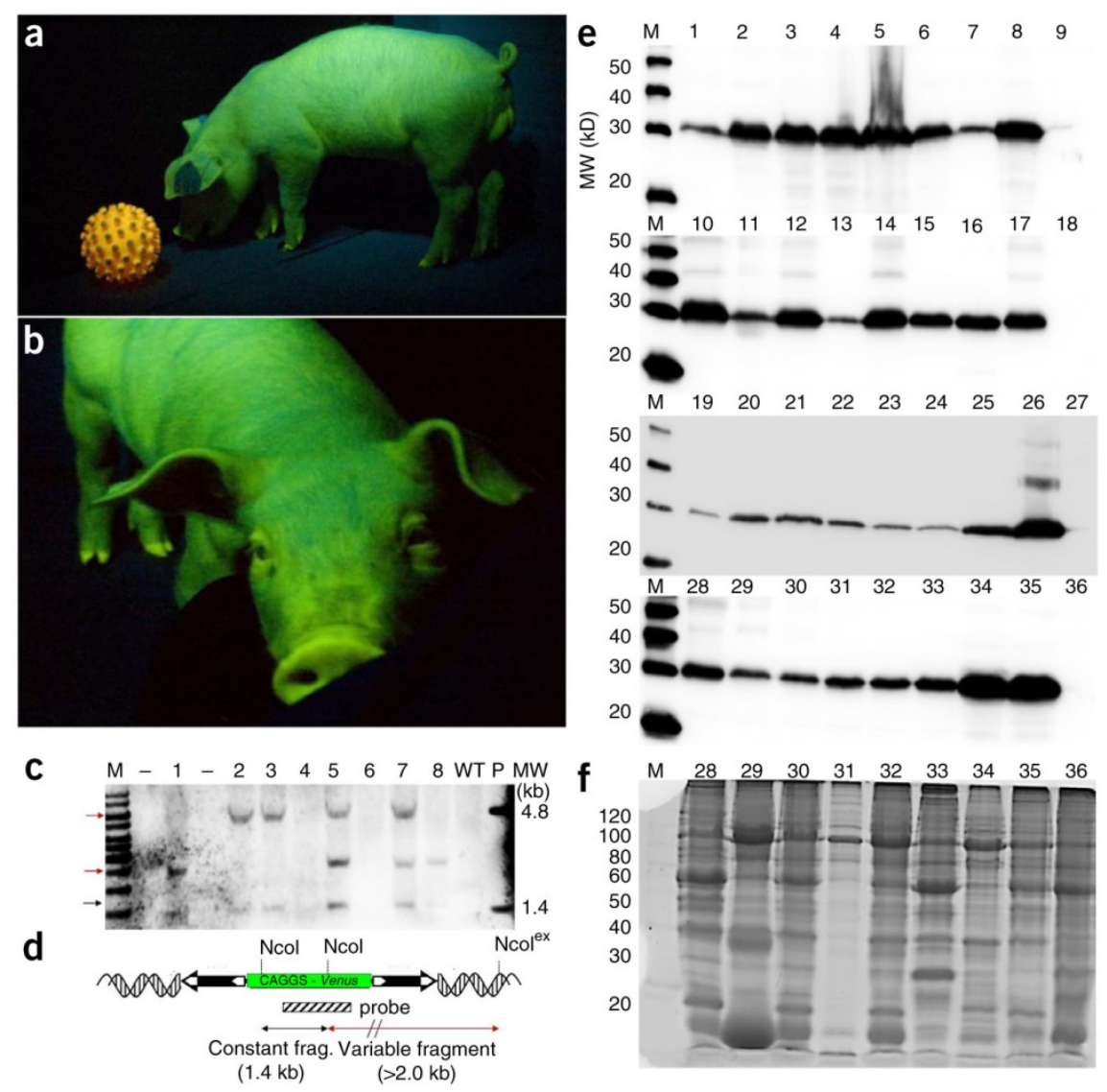

Figure 7. Live imaging of piglets transgenic for a Venus-tagged SB transposon. (a) Venus-

transposon transgenic founder boar (F0) shown under specific excitation. (b) The same animal from the front. Note the homogenous fluorescence of all body surfaces. Animal experiments were carried out under the appropriate institutional regulatory board permission. (c) Genotyping of F1 offspring by Southern blotting. Genomic DNA was restricted with Ncol, resulting in a constant (internal) fragment (black arrow) of the Venus transposon and a flanking fragment of variable size (red arrows) per each transgene integration. (d) Schematic of a genomically integrated SB transposon carrying a CAGGSVenus expression cassette. The approximate positions of the $\mathrm{Ncol}$ restriction endonuclease cleavage sites and the DNA fragment used as a probe in Southern hybridization are indicated. Drawing not to scale. (e) Ubiquitous expression of Venus as assessed by Western blotting of several organ samples (10 microgram protein per lane) of an $\mathrm{F} 1$ animal carrying a monomeric transposon: $\mathrm{M}$, molecular size marker; 1, skin (from the underside); 2, subcutis; 3, liver sample a; 4 liver sample b; 5, pancreas; 6 , spleen; 7 , spleen fat pad; 8 , liver fat pad; 9, negative control (tissue sample of wild-type animal); 10 , 
diaphragm; 11, lung; 12, heart; 13 heart fat pad; 14, aorta; 15, stomach; 16, oesophagus; 17, tongue; 18, negative control (tissue sample of wild-type animal); 19, salivary gland; 20, trachea; 21 , cortex of CNS; 22, brain stem; 23, cerebellum; 24, skin (back), 25, skin (head); 26, subcutis (back); 27, negative control (tissue sample of wild-type animal); 28, kidney; 29 kidney fat pad; 30, adrenal gland; 31, intestine; 32, colon; 33, ileum; 34, skeletal muscle sample a; 35 , skeletal muscle sample b; 36 , negative control (tissue sample of wild-type animal). (f) Coomassie-stained $10 \%$ SDS polyacrylamide gel of the loading controls of samples 28-36.

Supplementary Video 1. Copy number-dependent fluorescence in F2-generation piglets. The F2 litter of piglets are derived from the crossbreeding of two lines. Each founder carried three monomeric Venus-transposons, which segregated individually during meiosis. The piglets shown carry 0 to 5 copies of the Venus-transposon, and the fluorescent intensity correlates directly with the genotype. The "bluish" piglet in the back is a non-transgenic littermate. 

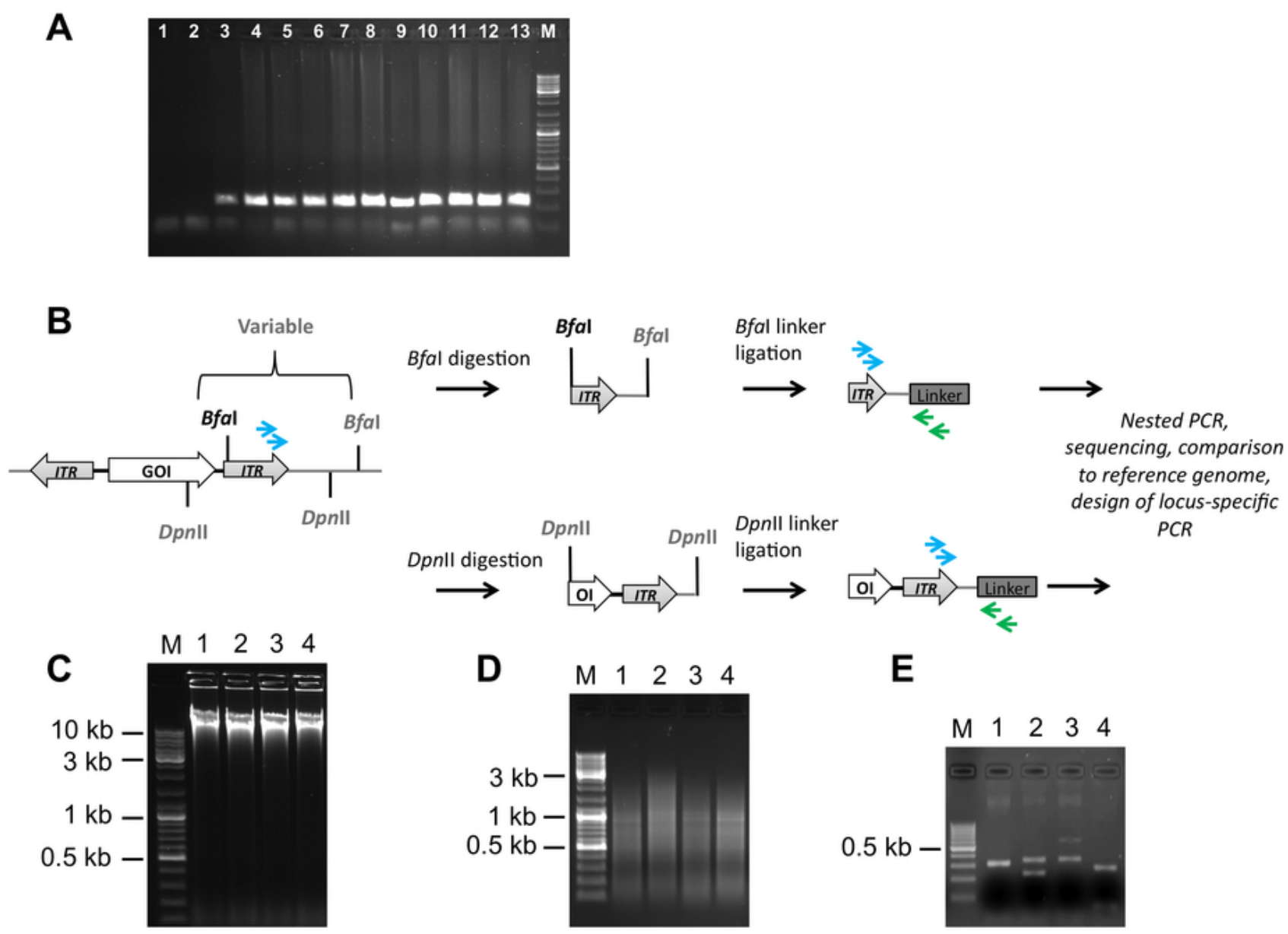

E

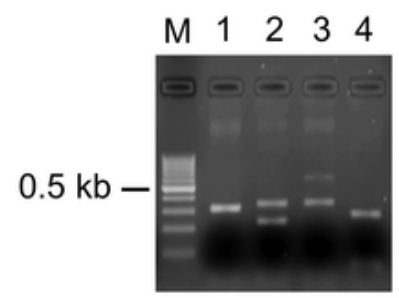

\section{Supplementary Figure 1: Identification of genomic transgene integration by PCR.}

(a) Identification of integrated transposon sequences from mouse genomic DNA samples by PCR with primers that amplify the left ITR of SB. Lanes: 1) $\mathrm{H}_{2} \mathrm{O}$; 2) mouse genomic DNA, negative control; 3) mouse genomic DNA, positive control; 4) transgenic founder \#1; 5-9) F1 offspring of transgenic founder \#1; 10) transgenic founder \#2; 11-13) F1 offspring of transgenic founder \#2; M) 100-bp molecular size marker. (b) Ouline of the LMPCR procedure. Digestion of genomic DNA with the frequently cutting restriction enzymes BfaI and DpnII and ligation of linkers with a known sequence allows for specific LMPCR amplification of transposon/genomic DNA junctions using primers specific to the transposon ITR (blue arrows) and the linkers (green arrows). GOI, gene of interest; ITR, inverted terminal repeat. (c) Agarose gel with genomic DNA samples. Lanes 1-4) genomic DNA samples of rat founders, 500 ng each; M) DNA size marker. (d) Agarose gel with genomic DNA samples digested 
with BfaI restriction endonuclease. Lanes 1-4) BfaI-digested DNA samples of rat founders, $200 \mathrm{ng}$ each; M) DNA size marker. (e) Agarose gel with LMPCR products. Lanes 1-4) result of nested PCR following BfaI linker ligation; M) DNA size marker. 

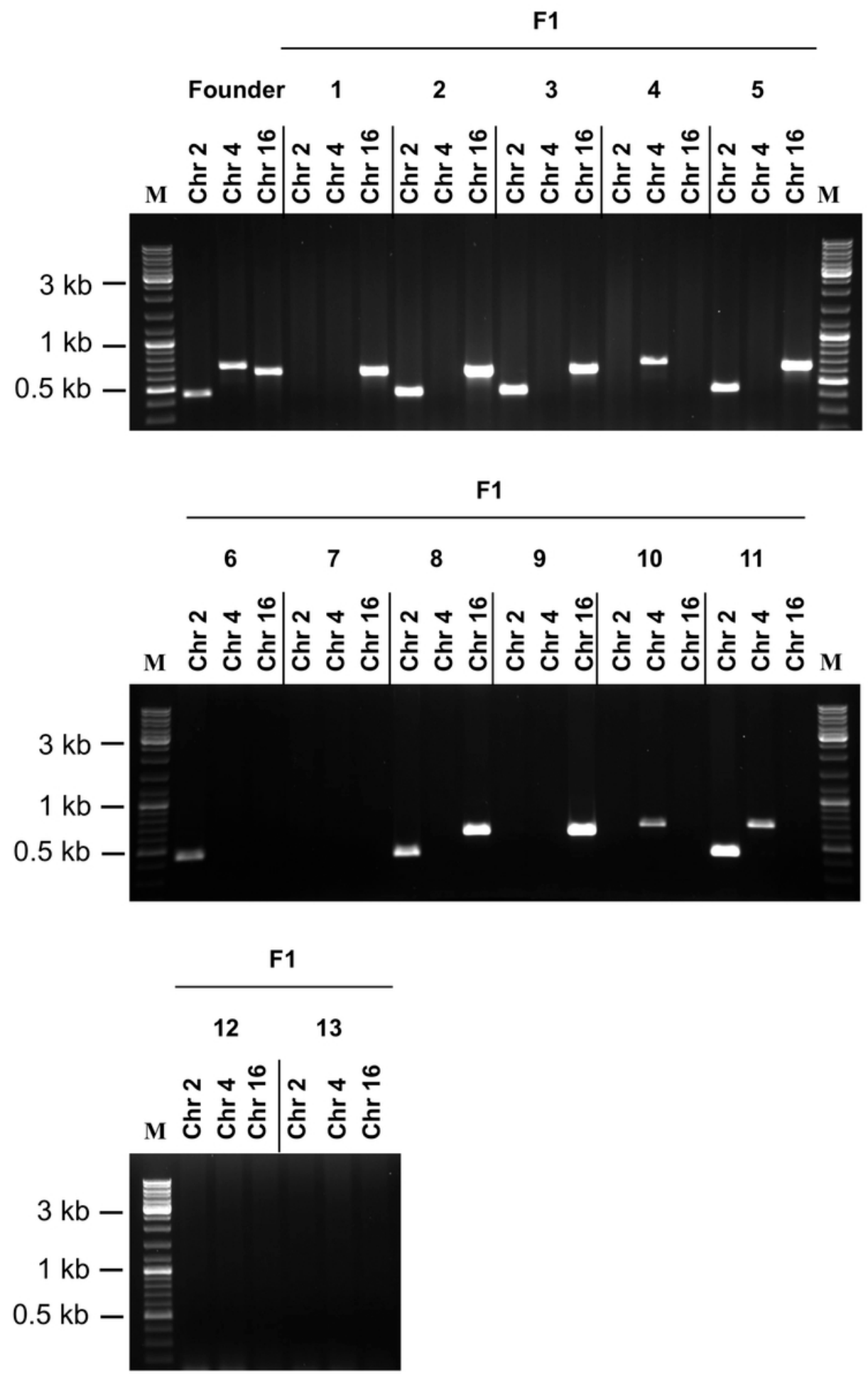

Supplementary Figure 2: Locus-specific PCR test of a rat founder and its F1 descendants.

The founder of these F1 animals carried three SB integrations (in chr2, chr4 and chr16), which were transmitted to 13 descendants in different combinations. M, DNA size marker. 
Table 1. Primer sequences.

\begin{tabular}{|c|c|c|}
\hline $\begin{array}{l}\text { Oligo } \\
\text { designation }\end{array}$ & Sequence & Description and use \\
\hline SB short & 5'-TACAGTTGAAGTCGGAAGTTTACATAC-3' & $\begin{array}{l}\text { Transposon-specific } \\
\text { primer used in PCR with } \\
\text { Tbal rev. Step } 81\end{array}$ \\
\hline Tbal rev & 5'-GAATTGTGATACAGTGAATTATAAGTG-3' & $\begin{array}{l}\text { Transposon-specific } \\
\text { primer used in PCR with } \\
\text { SB short. Step } 81\end{array}$ \\
\hline Linker(+) & $\begin{array}{l}\text { 5'-GTAATACGACTCACTATAGGGCTCCG } \\
\text { CTTAAGGGAC-3' }\end{array}$ & $\begin{array}{l}\text { Annealed either with } \\
\text { Linker(-) Bfal or Linker(-) } \\
\text { Dpnll to form double } \\
\text { stranded linker for LM- } \\
\text { PCR. Step } 95\end{array}$ \\
\hline Linker(-)Bfal & 5'-p-TAGTCCCTTAAGCGGAG-Amino-3' & $\begin{array}{l}\text { Annealed with Linker(+). } \\
\text { The 3' C7 amino } \\
\text { modification prevents } \\
\text { polymerase extension. } \\
\text { Step } 95\end{array}$ \\
\hline Linker(-)Dpnll & 5'-p-GATCGTCCCTTAAGCGGAG-Amino-3' & $\begin{array}{l}\text { Annealed with Linker(+). } \\
\text { The 3' C7 amino } \\
\text { modification prevents } \\
\text { polymerase extension. } \\
\text { Step 95 }\end{array}$ \\
\hline Linker Primer & 5'-GTAATACGACTCACTATAGGGC-3' & $\begin{array}{l}\text { Linker-specific primer } \\
\text { used in the first round of } \\
\text { PCR with Tbal rev3s } \\
\text { (transposon specific). } \\
\text { Step 98 }\end{array}$ \\
\hline Tbal rev3s & 5'-CATGACATCATTTTCTGGAATT-3' & $\begin{array}{l}\text { Transposon-specific } \\
\text { primer used in the first } \\
\text { round of PCR with } \\
\text { Linker Primer (linker } \\
\text { specific). Step } 98\end{array}$ \\
\hline Nested Primer & 5'-AGGGCTCCGCTTAAGGGAC-3' & $\begin{array}{l}\text { Linker-specific primer } \\
\text { used in the second } \\
\text { round of PCR with Tbal } \\
\text { (transposon specific). } \\
\text { Step } 100\end{array}$ \\
\hline Tbal & 5'-CTTGTGTCATGCACAAAGTAGATGTCC-3' & $\begin{array}{l}\text { Transposon-specific } \\
\text { primer used in the } \\
\text { second round of PCR } \\
\text { with Nested Primer } \\
\text { (linker specific). Step } \\
100\end{array}$ \\
\hline
\end{tabular}

